\title{
Empowerment and Efficiency: Tenancy Reform in West Bengal
}

\author{
Abhijit V. Banerjee \\ Massachusetts Institute of Technology \\ Paul J. Gertler \\ University of California, Berkeley \\ Maitreesh Ghatak
}

University of Chicago

The paper analyzes the effect of agricultural tenancy laws offering security of tenure to tenants and regulating the share of output that is paid as rent on farm productivity. Theoretically, the net impact of tenancy reform is shown to be a combination of two effects: a bargaining power effect and a security of tenure effect. Analysis of evidence on how contracts and productivity changed after a tenancy reform program was implemented in the Indian state of West Bengal in the late 1970s suggests that tenancy reform had a positive effect on agricultural productivity there.

\footnotetext{
We are grateful to the editor, Sherwin Rosen, and three anonymous referees for detailed comments, from which the paper benefited significantly. We are indebted to Maitreya Ghatak for his advice and support at all stages of the project, and especially in conducting the survey. Special thanks are due to Debraj Ray and Esther Duflo, whose valuable suggestions greatly influenced our approach. Thanks are also due to D. Bandyopadhyay, Nripen Bandyopadhyay, Pranab Bardhan, Tim Besley, Anne Case, Angus Deaton, Semanti Ghosh, Jonathan Gruber, D. Gale Johnson, Steve Levitt, Eric Maskin, Jonathan Morduch, Sunil Sengupta, and many seminar audiences for helpful feedback. We thank Ajoy Bhowmik, Lipi Ghatak, Arun Ghosh, Swapan Saha, and Nga Vuong for their help in the process of data collection, entry, and analysis. The usual disclaimer applies.
}

[Journal of Political Economy, 2002, vol. 110, no. 2]

(C) 2002 by The University of Chicago. All rights reserved. 0022-3808/2002/11002-0003 $\$ 10.00$ 


\section{Introduction}

While there is widespread support for reforming agricultural property rights (see, e.g., World Bank 1993; Binswanger, Deininger, and Feder 1995), there have been few attempts to evaluate the productivity consequences. ${ }^{1}$ Part of the reason is that there are few examples of largescale changes in property rights that were not accompanied by major social unrest. Moreover, analyzing the impact on efficiency is difficult because of data limitations and the fact that the structure of property rights is itself endogenous.

In this paper we study the effect of a major change in property rights on agricultural productivity in the Indian state of West Bengal. Within a year of being elected in 1977, a left-wing administration launched Operation Barga, a program designed to implement and enforce the long-dormant agricultural tenancy laws that regulated rents and security of tenure of sharecroppers. ${ }^{2}$ Under these laws, if tenants registered with the Department of Land Revenue, they would be entitled to permanent and inheritable tenure on the land they sharecropped as long as they paid the landlord at least 25 percent of output as rent. In the decade following the launching of Operation Barga, there was a significant improvement in the terms of tenants' contracts and more secure tenure. Moreover, agricultural productivity grew faster in West Bengal compared to other states in India, earning the administration praise from many, sometimes unexpected, quarters. ${ }^{3}$

An evaluation of the contribution of Operation Barga to the agricultural growth in West Bengal provides a rare opportunity to examine the relationship between property rights and efficiency. It also allows us to reexamine the question of whether there is a necessary trade-off between efficiency and equity in programs that transfer property rights from the rich to the poor. Operation Barga is especially interesting because it involved a limited transfer as opposed to a full transfer of property rights (e.g., redistributing landownership). It gave the incumbent tenant only the right to claim a higher share of the output and permanent tenure. While a full transfer of landownership that would completely eliminate agency costs is likely to have positive effects on productivity, the effect of a more limited transfer such as Operation Barga is less obvious.

Our theoretical analysis shows that the impact on productivity can be decomposed into two effects: a bargaining power effect and a security of tenure effect. The bargaining power effect comes from the fact that

\footnotetext{
${ }^{1}$ Exceptions include Lin (1992), Besley (1995), and Jeon and Kim (2000).

${ }^{2}$ Barga is the local word for sharecropper.

${ }^{3}$ See "Left Gets It Right" (1993), an article in the Economist on the Left Front's successful rural reforms in West Bengal.
} 
after the reform the legal contract becomes the tenant's "outside option," which increases his bargaining power vis-à-vis the landlord and forces the landlord to offer him a higher crop share, which translates into stronger incentives.

Security of tenure has two different opposing effects. On one hand, the landlord may use the threat of eviction when output is low to induce the tenant to work harder. ${ }^{4}$ Disallowing eviction restricts the use of such incentives and therefore reduces efficiency. On the other hand, greater security of tenure encourages the tenant to invest more since it gives him the confidence that he will stay on the land long enough to enjoy the fruits of his investment. Moreover, his increased bargaining power means that the tenant now expects to get a higher share of the additional output resulting from investment.

We also find empirical support for the hypothesis that the transfer of property rights under Operation Barga positively affected agricultural productivity. We take two approaches to measuring the impact on productivity. The first is a quasi-experimental approach using the neighboring country of Bangladesh, which is similar in many respects to West Bengal but did not implement tenancy reform. The second approach uses sharecropper registration as a measure of program intensity and tests whether productivity is higher in areas in which the program was implemented more intensively. Our results suggest that limited interventions in property rights like Operation Barga, which empower tenants without giving them full landownership, can have a positive effect on productivity. ${ }^{5}$ Hence there is no necessary trade-off between efficiency and equity in such programs. Moreover, these strategies of empowerment tend to be politically easier to implement than conventional land reforms. They may therefore offer a real way out of the status quo in the right context.

We have organized the presentation as follows. In Section II, we briefly describe Operation Barga. In Section III, we present our theoretical arguments about how Operation Barga is likely to have affected contracts and incentives, and we discuss results from a survey of sharecroppers that we carried out on how contracts actually changed in response to the reform. In Section IV, we present the analysis of the impact of Operation Barga on productivity using district-level data. Section V presents conclusions.

${ }^{4}$ This observation goes back to Johnson (1950). For a formal analysis, see Dutta, Ray, and Sengupta (1989).

${ }^{5}$ Other examples of strategies that could empower tenants are usury laws, minimumwage laws, job creation programs, and supply of subsidized credit. 


\section{Operation Barga}

After independence, India sought to improve the living standards of sharecroppers through tenancy reform. The Land Reforms Act of 1955 and its successive amendments have two main clauses: (1) Sharecroppers will have permanent and inheritable incumbency rights to land that is registered in their name provided that they pay the legally stipulated share to the landlords, do not leave the land fallow, and do not sublease the land. Except in such cases, the sharecropper will lose his right to the land only if the landlord wants to use the land for personal cultivation. These rights are inheritable but not transferable. (2) The share that the landlord can demand from a registered tenant will be no greater than 25 percent. $^{6}$

This phase of tenancy reform is widely recognized as a failure (Appu 1975). Loopholes in the law allowed landlords to abuse the personal cultivation exemption and to threaten to evict the tenant whenever he tried to register. Moreover, the tenant was responsible for registering himself, and the government provided little institutional support for him to do so. By virtue of their wealth and superior caste, landlords wielded a lot of power within the village and were therefore able to intimidate tenants. This was compounded by the fact that the government usually took the landlord's side in disputes. As a result, before Operation Barga, very few sharecroppers were registered, crop shares were significantly below the legal minimum, and tenure was widely perceived as being insecure (Bardhan and Rudra 1984).

In 1977, the newly elected government passed the West Bengal Land Reforms Act, which closed most of the loopholes in the 1955 act. Most important, it set very stringent and well-defined conditions under which the landlord could utilize the personal cultivation clause to evict a tenant.

At the same time, the new government launched Operation Barga, a massive and well-publicized village-to-village campaign to register tenants and ensure their rights. Under this program the process used to register tenants was altered to make it easier for the sharecropper to register. Operation Barga officials sought out hesitant sharecroppers, explained the law, and offered them the opportunity to register. Moreover, the new government used its own village political organizations to make sure that landlords did not intimidate tenants, that tenants who registered did not face reprisal from the landlords, and that disputes were handled fairly in the courts. Operation Barga is widely regarded as a success. By 1993, more than 65 percent of an estimated 2.3 million share tenants had been registered.

\footnotetext{
${ }^{6}$ In cases in which the landlord pays the cost of all nonlabor inputs, the law caps his share at 50 percent. However, this clause rarely applies.
} 


\section{Theory: Tenancy Reform, Contractual Change, and Productivity}

In this section we develop a simple theoretical model of a landlordtenant relationship based on moral hazard and limited wealth of tenants. We shall use this model to analyze the potential effects of the reform on the contractual relationship between a given landlord and an incumbent tenant.

There are two ways in which the reform could have altered the set of potential contracts between the landlord and the tenant. First, it changed an incumbent tenant's outside option. The fact that the landlord could no longer evict the tenant meant that the tenant could always hold out for his legal share of the output. The landlord could no longer threaten to replace him with another tenant if he refused to accept a lower share. This does not mean that the contract between them necessarily has to be the legally stipulated contract. Under some conditions there may be a different contract that suits them both better, but the tenant should not be worse off than he would be if he stuck to the letter of the law.

A second potential effect of the reform is directly related to the restrictions on eviction. Under the new law, the tenant could plan to crop the same piece of land for as long as he would like to without fearing eviction. On the other hand, the landlord could no longer expect to use the threat of eviction as a credible incentive device. One would expect the optimal contract to change for both these reasons. ${ }^{7}$

\section{A. The Model}

Suppose that there is an infinitely lived landlord who owns a plot of land that he cannot crop himself. In each period he employs exactly one tenant to crop the land. There is a large population of identical infinitely lived tenants who are all willing to work for the landlord as long as the landlord pays them their outside option (or reservation payoff), $m$, in that period, which is given exogenously. The landlord and the tenants share the same discount factor $\delta<1$. In each period, output can take on two values, $Y_{H}=1$ ("high" or "success") and $Y_{L}=0$ ("low"

\footnotetext{
${ }^{7}$ This is less obvious than it seems because the tenant and the landlord are not bound to honor the letter of the law in their mutual contracting. Thus, in principle, the two parties could continue using threats of eviction as an incentive device even after evictions are made illegal: the tenant can voluntarily agree to let the landlord evict him if he fails to produce enough. This possibility is likely to be limited by commitment problems on both sides. A tenant who is actually facing eviction may want to renege on his promise to leave quietly and may seek the protection of the law. Similarly, a landlord who has been given the right to evict by his tenant may be tempted to abuse his power to his bargaining advantage.
} 
or "failure"), with probability $e$ and $1-e$, respectively. The realizations of output are independent over time. The tenant chooses $e$ ("effort"), which costs him $c(e)$. For simplicity, we assume that the cost function is quadratic: $c(e)=\frac{1}{2} c e^{2}$. For reasons that will become apparent later, we assume $c>1$.

The key assumptions of this model are as follows: (1) Only the tenant's effort matters for output. ${ }^{8}$ (2) The tenant's effort choice $e$ is nonobservable and hence noncontractible. (3) Past and present realizations of output are contractible. Specifically, we assume that at the beginning of each period the landlord can commit himself to a one-period contract that maps current and past realizations of output into $(a)$ current payments to each potential tenant and $(b)$ a decision about which tenant will work for him in the next period. (4) The landlord faces a limited liability constraint. ${ }^{9}$ In particular, in a given period, each tenant has a limited amount of wealth $w>0$, so that the least he can get paid is $-w .^{10}$ (5) Both the tenant and the landlord are risk-neutral. ${ }^{11}$

The fact that both the landlord and the tenants are infinitely lived defines an infinite extensive-form game between the landlord and the tenant that, in principle, can have many equilibria. Here we restrict ourselves to studying equilibria of this game in which the strategies in each period are history-independent except for the choice of who is going to be the landlord's current tenant. ${ }^{12}$ Furthermore, consistent with the assumption that there are many potential tenants and one landlord, we shall focus on the equilibrium that maximizes the landlord's profits per period.

In this game there is no reason to pay those tenants who are not working for the landlord in the current period, so the contract needs to specify only payments to the tenant who is currently working for the landlord. Likewise, the landlord has no reason to discriminate among those who are not working for him in the current period. Therefore,

\footnotetext{
${ }^{8}$ Eswaran and Kotwal (1985) have argued that the landlord sometimes contributes to agricultural production by providing managerial inputs. In a previous version of the paper, we argue that our results continue to hold in this case.

${ }^{9}$ There are models of sharecropping based on moral hazard that do not use the hypothesis of limited liability (see Stiglitz 1974).We use it because it provides an analytically simple way of generating rents for the tenant (which is necessary for threats of eviction to be meaningful) as well as the static inefficiency associated with tenancy. See Dutta et al. (1989) and Mookherjee (1997) for similar models of sharecropping based on limited liability.

${ }^{10}$ We are assuming that tenants do not save and nonmonetary punishments are not allowed. Ghatak, Morelli, and Sjöström (2001) and Mookherjee and Ray (2000) study the implications of allowing saving by agents in similar environments.

${ }^{11}$ In a previous version of the paper, we showed that the same results hold when the tenant is risk-averse, as long as the limited liability constraint binds in equilibrium.

${ }^{12}$ Formally we are looking at Markov equilibria in which the state variable is the identity of the current tenant (Fudenberg and Tirole 1991). Dutta et al. (1989) study historydependent Markov equilibria in a similar environment.
} 
if and when he decides to get a new tenant, he can simply choose randomly from among those who are not working for him currently (here we make use of the assumption that there are many potential tenants; otherwise the landlord would randomize only among those who have never worked for him). Furthermore, by the assumption of history independence, the contract for each tenant will just depend on the current realization of output. Therefore, the contract in any given period will just need to specify four numbers: the payment to the tenant and the probability of his continuing in the job when the output is high (denoted, respectively, by $h$ and $\varphi$ ) and the same two numbers when output is low $(l$ and $\psi)$. We shall find it convenient to refer to $h$ and $l$ as success and failure wages. Note that we could have, instead, conducted our analysis in terms of a linear contract, $s Y-r$, with $s$ denoting the crop share of the tenant and $r$ a fixed-rent component, with $s=h-l$ and $r=$ $-l$. The reason is that since output takes only two values in this model, all contracts can be expressed as linear contracts.

\section{B. Optimal Tenancy Contracts without Eviction}

We first solve the landlord's problem under the assumption that incumbent tenants cannot be evicted and will therefore continue to be the tenant in all future periods. In this case the problem reduces to solving the one-period contracting problem. Given the tenant's outside option $m$ and wealth level $w$, the optimal contract is a solution of maximizing the landlord's expected payoff,

$$
\max _{\{e, h, l\}} \pi=e-[e h+(1-e) l],
$$

subject to the following constraints: (i) The limited liability constraint (LLC) requires that the amount of money that could be taken away from the tenant in any state of the world is bounded above by his wealth $w$ and realized output:

$$
h \geq-(1+w), \quad l \geq-w .
$$

(ii) The participation constraint of the tenant requires that the contract guarantees an expected payoff to the tenant equal to $m$ :

$$
v=e h+(1-e) l-\frac{1}{2} c e^{2} \geq m .
$$

(iii) The incentive-compatibility constraint (ICC) requires that the tenant chooses the effort level $e$ to maximize his private payoff:

$$
e=\arg \underset{e \in[0,1]}{\max }\left\{e h+(1-e) l-\frac{1}{2} c e^{2}\right\} .
$$


Notice that the optimal incentive contract $(h, l)$ must have $h>l$ because if $h \leq l$, then from the incentive-compatibility constraint, $e=0$ and the landlord gets $-l$; for the same $l$, if he sets $1 \geq h>l$, he gets $e[1-(h-l)]-l \geq-l$. This also implies that one of the two LLCs, $h \geq$ $-(1+w)$, cannot bind. The total expected surplus generated by a project is $S=e-\left(c e^{2} / 2\right)$. The first-best level of $e$, namely the one that maximizes $S$, is $1 / c<1$ (by our assumption that $c>1$ ). Since the constraint that $e \leq 1$ does not bind at the first-best, we can safely ignore it. This also implies that there is no reason to choose $h-l>1$ since the first level of effort and output is achieved when $h-l=1$. Hence the ICC can be rewritten as

$$
e=\frac{h-l}{c} \in(0,1)
$$

Let us substitute for $e$ using the ICC and rewrite the optimal contracting problem of the landlord as

$$
\max _{\{h, l\}} \pi(h, l)=\frac{h-l}{c}-\frac{(h-l)^{2}}{c}-l
$$

subject to

$$
\frac{(h-l)^{2}}{2 c}+l \geq m
$$

and $l \geq-w$.

Consider first the case in which the participation constraint does not bind. Observe that in this case it is always optimal to reduce $l$ down to $-w$ while keeping $h-l$ unchanged. With $l$ set at $-w$, the value of $h-$ $l$ that maximizes profits is easily determined by differentiating the expression for $\pi$ with respect to $h-l$. This yields $h-l=\frac{1}{2}$, implying $e=1 / 2 c$. Substituting these values into the participation constraint, we can write it as $1 / 8 c \geq m+w$. As long as $m$ and $w$ are low enough that this constraint does not bind, we are justified in ignoring the participation constraint. For this case the optimal value of $e$ is therefore $e^{*}=1 / 2 c$.

Next consider the case in which $1 / 8 c<m+w$. In this case the participation constraint will bind. Substituting the value of $l$ from the participation constraint into the expression for $\pi$ gives us

$$
\pi(h, l)=\frac{h-l}{c}-\frac{(h-l)^{2}}{2 c}-m .
$$

This expression is maximized when $h-l=1$, which represents a pure 
rent contract. ${ }^{13}$ Consequently, $e$ will be at its first-best level, $1 / c$. Combining $h-l=1$ with the fact that the participation constraint binds, we get the condition $l=m-(1 / 2 c)$. Since the LLC requires that $l \geq$ $-w$, we conclude that the first-best level of $e$ will be chosen only if $m-(1 / 2 c) \geq-w$ (otherwise the LLC will bind), which is equivalent to $m+w \geq 1 / 2 c$.

Finally, for intermediate values of $m+w$, that is, $1 / 8 c \leq m+w<$ $1 / 2 c$, both the participation constraint and the LLC will bind. Solving these together, we get $l=-w$ and $h-l=\sqrt{2 c(m+w)}$, and using the ICC, we get the optimal value of $e$,

$$
e^{*}=\sqrt{\frac{2(m+w)}{c}} .
$$

There are two results from this analysis that are relevant in studying the effect of the reform.

Result 1 . The value of $e$ implied by the optimal contract between the landlord and the tenant is

$$
e^{*}= \begin{cases}\frac{1}{2 c} & \text { if } m+w<\frac{1}{8 c} \\ \sqrt{\frac{2(m+w)}{c}} & \text { if } \frac{1}{8 c} \leq m+w<\frac{1}{2 c} \\ \frac{1}{c} & \text { if } \frac{1}{2 c} \leq m+w .\end{cases}
$$

Hence an improvement in the incumbent tenant's outside option always (weakly) increases effort.

RESUlt 2. The tenant's participation constraint does not bind as long as $m+w<1 / 8 c$ and hence he earns rents.

These results have simple intuitions. The main trade-off the landlord faces in this model is either to provide incentives or to extract surplus from the tenant. A fixed-rent contract, where the tenant pays the same amount whether or not his output is high, maximizes the tenant's incentives and would always be chosen if the tenant were wealthy enough. However, since the tenant cannot pay more than he has, the fixed rent is bounded above by his wealth, $w$ (this is all he has when his crop fails). Therefore, if $w$ is small, fixed-rent contracts are not in the landlord's interest. The landlord can do better with a contract that makes the tenant pay more when he has more (i.e., when his output is high). However, this clearly taxes success and therefore weakens incentives. This explains why the expected output is less than first-best. However,

\footnotetext{
${ }^{13}$ It is easy to verify that this contract pays the landlord $w$ in both states of the world, making the tenant a full residual claimant.
} 
as the tenant becomes wealthier, it becomes easier to extract rents from him without sacrificing incentives and expected output approaches the first-best. ${ }^{14}$

An increase in the outside option of the tenant, $m$, forces the landlord to pay the tenant more. Since the tenant typically has too little incentives, the landlord will want to pay him this extra amount in the form of an extra bonus for success, which will give the tenant stronger incentives to work hard. This result forms the basis of what we call the bargaining power effect of the reform: an increase in the tenant's bargaining power, with everything else held constant, leads to an increase in his share and his productivity.

Finally, the tenant may earn rents in this model because if he has very little wealth and his outside options are very low, then the only way the landlord can extract the entire surplus from the tenant (net of $m$ ) is to take away almost all of the output when output is high. Since this obviously has adverse incentive effects, the landlord will typically not try to extract the entire surplus when $m$ is very low. Hence the landlord will not reduce the share of the tenant below some minimum level irrespective of $m^{15}$

The curve $A B C D$ in figure 1 shows equilibrium effort as a function of the tenant's outside option and wealth level when eviction threats are absent.

\section{Optimal Tenancy Contracts with Eviction}

We now turn to the situation in which the landlord can evict the tenant at will. In this case the landlord can typically do better than offering the one-shot contract described above. One feature of the one-shot contract is the fact that the tenant earns rents unless his outside option is sufficiently good: this means that the tenant will strictly prefer to continue being a tenant; therefore, the threat of eviction if output is low can be used as an incentive device. ${ }^{16}$

Let $\bar{V}$ denote the expected equilibrium lifetime utility of an incumbent tenant in the next period. Let $M$ denote the equilibrium lifetime expected utility of someone who is currently not a tenant: $M \equiv m /(1-$

\footnotetext{
${ }^{14}$ Laffont and Matoussi (1995), Bandiera (1999), and Ackerberg and Botticini (2002), among others, find evidence for a positive wealth effect on the tenant's share of output.

${ }^{15}$ This problem is similar to that of raising income tax revenue by the government: low taxes will lead to high levels of labor supply and income but will yield low revenue. Result 2 is similar to the idea behind the Laffer curve: higher tax rates may reduce labor supply so much that the government may earn less tax revenue.

${ }^{16}$ The threat of evicting the incumbent tenant is credible from the landlord's point of view because, by assumption, tenants of all types (in terms of wealth and outside options) are available in unlimited numbers. As a result the landlord is indifferent between retaining and firing a given tenant.
} 


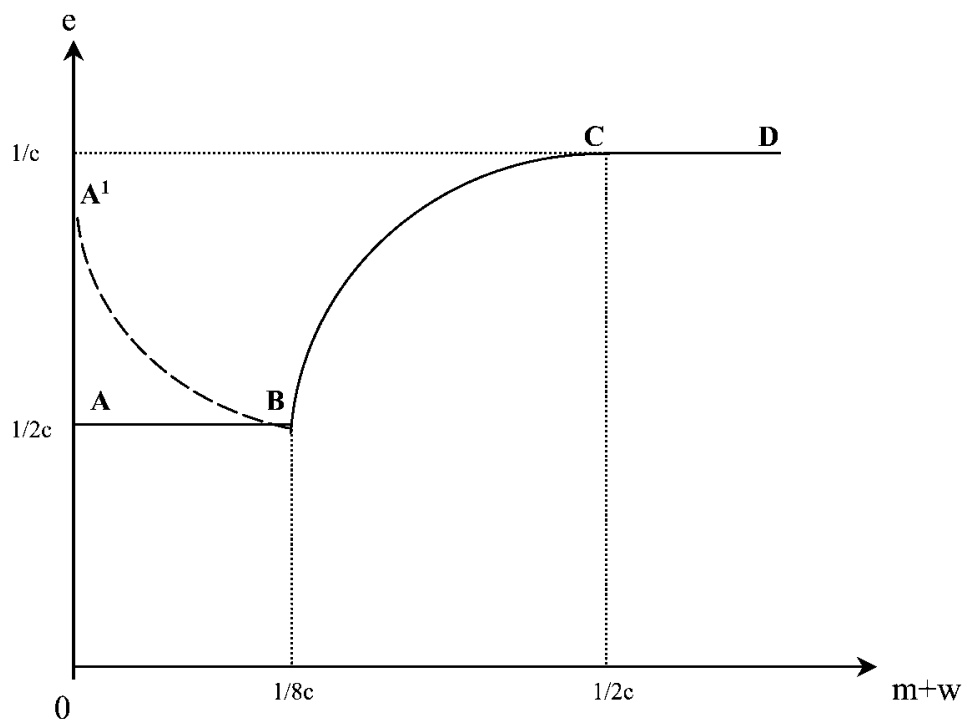

FIG. 1

$\delta)$, where, as before, $m$ is the value of the outside option per period. The hypothesis of history independence implies that the landlord cannot precommit anything beyond the current-period incentive contract, $(h, l)$, and the corresponding probabilities of eviction, $(1-\varphi, 1-\psi)$. It also implies that the tenant's lifetime utility from next period onward, $\bar{V}$, is taken as exogenous in this period by both players.

Given these assumptions, the tenant's expected lifetime utility in the current period from choosing a level of effort $e$ today, $\bar{V}_{0}$, must satisfy the Bellman equation: ${ }^{17}$

$$
\begin{aligned}
\bar{V}_{0}= & \max _{\{e \in[0,1]\}}\{e h+\delta[\varphi e+(1-e) \psi](\bar{V}-M)+\delta M \\
& \left.-(1-e) w-\frac{1}{2} c e^{2}\right\} .
\end{aligned}
$$

Differentiating this expression with respect to $e$ yields the new ICC:

$$
h+w+\delta(\bar{V}-M)(\varphi-\psi)=c e .
$$

Comparing this with the ICC in the one-shot game, we see that the

${ }^{17}$ Here we assume that the LLC binds, i.e., $l=-w$. If it does not bind, there will be no rents and the threat of eviction would have no effect. 
existence of rents and the tenant's foresight reduce the marginal cost of implementing $e$ by the amount $\delta(\bar{V}-M)(\varphi-\psi)$.

Next we observe that $\varphi=1$ and $\psi=0$ in the optimal dynamic contract. As long as the tenant is still getting more than his outside option, raising the probability of eviction is preferred by the landlord rather than raising $h$ for giving more incentives because it is costless from his point of view. Neither $\varphi$ nor $\psi$ affects the landlord's payoff directly (as long as the participation constraint is not binding), and the only thing they affect is the ICC. Hence from (2) we see that $\psi$ should be set at its minimum possible value, zero, to give the maximum punishment to the tenant for failure. On the other hand, $\varphi$ should be set at its maximum possible value, one, to maximally reward the tenant for success.

Thus (2) becomes

$$
h+w+\delta(\bar{V}-M)=c e .
$$

The new participation constraint of the tenant is $\bar{V}_{0} \geq M .{ }^{18}$ In a stationary equilibrium, $\bar{V}_{0}=\bar{V}$, and hence from (1) we get

$$
\bar{V}-M=\frac{e h-(1-e) w-\frac{1}{2} c e^{2}-m}{1-\delta e} .
$$

Substituting (3) into (4), we get

$$
\bar{V}-M=\frac{1}{2} c e^{2}-w-m .
$$

In any equilibrium in which eviction threats are used, $\bar{V}-M$ must be positive. If it is positive, the landlord has to maximize

$$
\max _{\{e, h, l\}} e(1-h)-(1-e) l
$$

subject to the ICC, (3), and the LLC. Using these two constraints, we can rewrite the landlord's objective function as

$$
\max _{\{e\}}\{1-c e+\delta(\bar{V}-M)\} e+w .
$$

Maximizing this leads to the first-order condition

$$
1-2 c e+\delta(\bar{V}-M)=0
$$

\footnotetext{
${ }^{18}$ This reflects the fact that in this case, in contrast to the case in which evictions are not allowed, the tenant faces a trade-off between current and future rewards. For that reason, the right comparison is made between his lifetime expected utility and his lifetime outside option.
} 


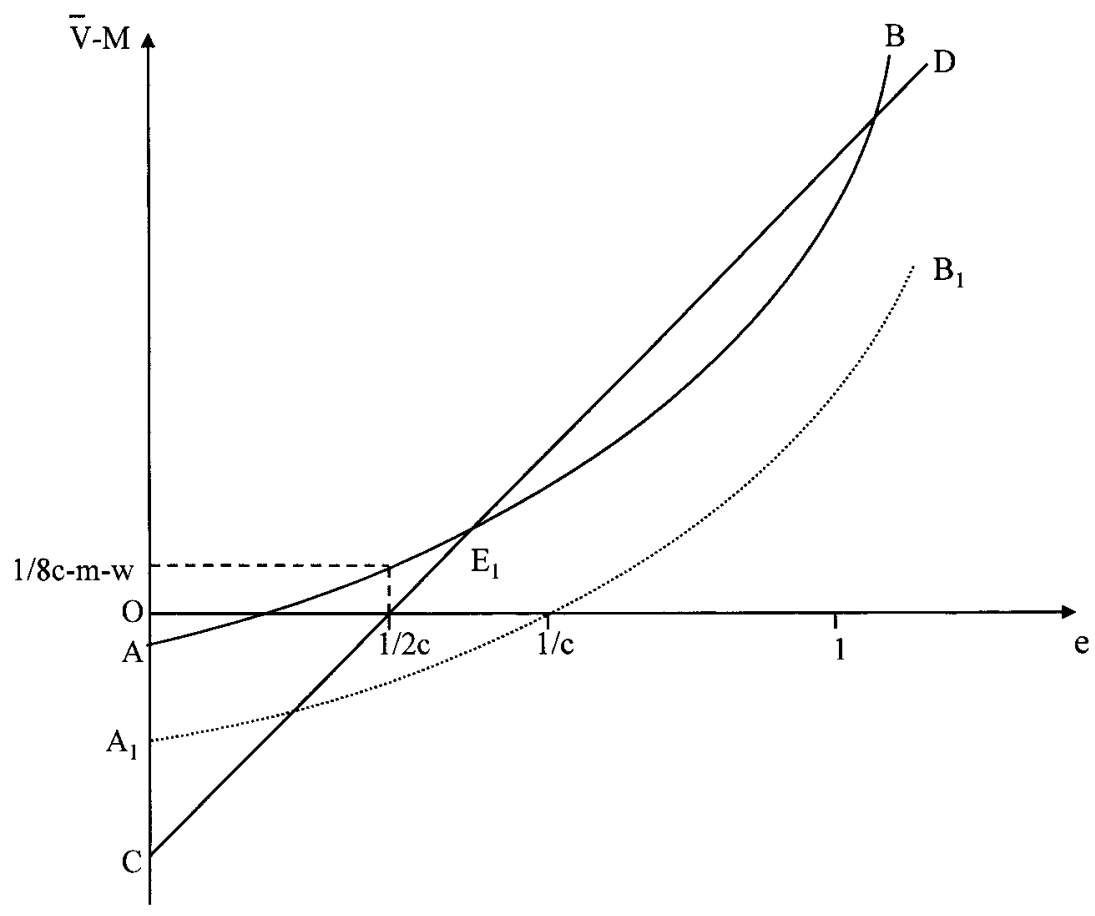

FIG. 2

which can be rewritten in the form

$$
e=\frac{1+\delta(\bar{V}-M)}{2 c}
$$

We can find the equilibrium values of $e$ and $\bar{V}$ by solving equations (5) and (8) simultaneously. In figure $2, A B$ and $C D$ represent equations (5) and (8). These curves intersect at two points, $E_{1}$ and $E_{2}$. The curve $A B$ is strictly increasing and convex, whereas $C D$ is a positively sloped straight line. For $e=1 / 2 c, C D$ intersects the horizontal axis. As long as $(1 / 8 c)-m-w>0$, the curve $A B$ lies above $C D$ at $e=1 / 2 c$. Also, for $e=1, C D$ lies above $A B \cdot{ }^{19}$ Hence only the point $E_{1}$, which corresponds to a value of $e \in(1 / 2 c, 1 / c)$, is an admissible solution since $E_{2}$ corresponds to a value of $e>1$. As $m+w$ increases (but with $[1 / 8 c]-m-$

${ }^{19}$ The relevant condition is $(2 c-1) / \delta>\frac{1}{2} c-w-m$. Since $c>1$ and $\delta<1, \quad[2-$ $(\delta / 2)] c>1$, which can be rearranged as $(2 c-1) / \delta>c / 2$. 
$w>0$ continuing to hold), the curve $A B$ moves down, and therefore the equilibrium value of $e$ will also go down. This is intuitive since the rents and hence the force of the threat of eviction should be smaller when either $m$ or $w$ is higher.

Let us now turn to the optimal share of the tenant, $h^{*}-l^{*}$. Substituting (3) into (7) and using the LLC, we see that

$$
h^{*}-l^{*}=\frac{1}{2}-\delta \frac{1}{2}(\bar{V}-M) .
$$

Since $\bar{V}-M$ goes down when $m+w$ goes up, $h^{*}-l^{*}$ must go up.

For the case in which $(1 / 8 c)-m-w<0$, the curve $A_{1} B_{1}$ represents equation (5) and is obtained by a vertical downward shift of $A B$. In this case it is clear that the two points at which $A_{1} B_{1}$ and $C D$ intersect involve $e<1 / 2 c$ and $e>1$ (the second intersection is not shown in the figure), and none of them are admissible. In this case there is no solution to the optimal contracting problem with eviction where the participation constraint does not bind (i.e., the equilibrium value of $\vec{V}-M$ is positive). Solving the participation equation (5), we get $e^{*}=\sqrt{2(m+w) / c}$, which is of course exactly the value of $e^{*}$ we found when eviction was not an option, under the assumption that $1 / 2 c \geq m+w \geq 1 / 8 c$. The optimal choice of the tenant's share, $h^{*}-l^{*}$, is also exactly the same as in the no-eviction case. This is as we would expect: when the participation constraint binds, the fact that eviction is an option should be irrelevant.

The rule that $e^{*}=\sqrt{2(m+w) / c}$ applies only as long as $e^{*} \leq 1 / c$, that is, as long as $m+w \leq 1 / 2 c$. For $m+w>1 / 2 c$, effort will be set at its firstbest level, that is, $e^{*}=1 / c, h^{*}-l^{*}=1$, and the LLC will no longer bind. This, once again, is exactly as in the case without eviction.

The curve $A^{1} B C D$ in figure 1 shows equilibrium effort as a function of the tenant's outside option when evictions are permitted. It differs from the corresponding curve $A B C D$ for the one-period model only for the range of values of $m$ such that the tenant earns rents $(m+w<$ $1 / 8 c)$. However, for $m+w<1 / 8 c, e^{*}$ is a declining function of $m$ when eviction is an option, whereas it is constant when eviction is forbidden. Moreover, since the two curves meet at $m+w=1 / 8 c$, it follows that the supply of effort is strictly higher when eviction threats are possible, for $m+w<1 / 8 c$. The discussion above is summarized in the following result.

RESUlt 3. When evicting the tenant is an option, the optimal choice of $e$ and $h-l$ coincides with that for the no-eviction case as long as $m+w \geq 1 / 8 c$. For $m+w<1 / 8 c$, the value of $e$ chosen with evictions is strictly higher than the corresponding value without evictions. Moreover, over this range, a higher $m$ is associated with a lower choice of $e$ but a higher value of $h-l$.

This result shows why the effect of Operation Barga on efficiency 
could be negative in spite of the bargaining power effect described in Section IIIB. Eviction threats will tend to raise the effort level of very poor tenants, and unless the increase in $m$ is large enough, their effort will fall as a result of the reform, though these tenants will still be better off. ${ }^{20}$ However, this analysis applies only to tenants who have a large number of close substitutes so that threats of eviction are credible. This excludes wealthier and more able tenants.

\section{Operation Barga and Investment Incentives}

The way we have modeled the production technology so far ignores any role of investment. It is often argued that tenurial insecurity discourages investment by the tenant, and this usually forms the strongest efficiency (as opposed to redistributive) argument in favor of tenancy or land reform. This argument typically fails to tell us why the landlord himself cannot undertake such investments directly (given that he is less likely to be credit-constrained than the tenant) or indirectly, by giving incentives to the tenant through suitable contractual means. It is clear that when the investment is contractible (e.g., flattening the land, building soil partitions, planting trees, and digging ponds), the problem cannot be the tenant's unwillingness to invest since the landlord can pay the tenant to invest. The problem is rather that the landlord may not want to invest at the first-best level: given that the tenant's effort is below the first-best level for agency reasons, the value of any investment that is complementary to the tenant's effort will also be below the first-best level, and as a result, the landlord will be reluctant to invest. In this case, Operation Barga can increase investment, but only because it increases the tenant's willingness to put in effort.

Noncontractible investments-such as experimentation with new techniques, the care and maintenance of the land, or the use of manure (the effect of which lasts more than one period)-differ from contractible investments because they create the possibility of a holdup problem unless the landlord can make long-term commitments. ${ }^{21}$

We use a simple two-period extension of our benchmark model of Section III $B$ to illustrate the point. Assume that in the first period the model is as before, but now the tenant can make a land-specific investment of amount $x$, which increases the productivity of the land in

\footnotetext{
${ }^{20}$ In an eviction equilibrium, $h$ is lower and $e$ is higher than in the no-eviction equilibrium; the tenant's utility per period has to be lower. And since the discount factor of the tenant is lower in an eviction equilibrium than in the no-eviction equilibrium (i.e., $\delta e<$ $\delta)$, the tenant's expected lifetime utility is lower as well.

${ }^{21}$ Similar conclusions emerge if the source of noncontractibility of investment is moral hazard (as it is for effort) instead of the landlord's inability or unwillingness to commit to long-term contracts. The analysis is, however, much more complicated (see Banerjee and Ghatak 1996).
} 
the second period in the following way: output is $Y_{H}=1+x$ with probability $e$ and $Y_{L}=x$ with probability $1-e$. This investment costs $\frac{1}{2} \gamma x^{2}$ to the tenant. We assume for simplicity that the second period's payoff is not discounted, $w=0$, and $m<1 / 8 c$.

If $x$ was contractible, then the landlord could simply "buy" it from the tenant at the efficient level, $1 / \gamma$. Even if $x$ is not contractible, the efficient level of investment can still be achieved as long as the landlord can commit to a two-period contract with the incumbent tenant. Let $r_{h} \equiv Y_{H}-h$ and $r_{l} \equiv Y_{L}-l$ denote the landlord's payoff when output is high and low, respectively. If in the current period the optimal contract is $\left(r_{h}, r_{l}\right)$, then by committing to retaining the current tenant next period and increasing the rent by a fixed amount $\Delta r$ in the next period irrespective of output, the landlord can make the tenant a full residual claimant of the fruits of his investment.

The interesting case of this model is the case in which $x$ is not contractible and it is also not possible for the landlord to commit to rewarding the tenant if he makes the investment. In this case the tenant anticipates that the landlord is going to expropriate the results of his first-period investment by threatening to fire him at the beginning of the second period. As a result the tenant will not invest at all, and so in both periods the outcome will be the same as in the one-period model, that is, $e=1 / 2 c, r_{h}=\frac{1}{2}$, and $r_{l}=0$. Hence if the landlord cannot precommit to future contracts, his total (two-period) expected payoff is $1 / 2 c$ and that of the tenant is $1 / 4 c$.

A possible benefit of Operation Barga in this context is that it rules out all evictions and therefore makes it possible for the landlord to convince the tenant that he will not be evicted. In this respect, both the landlord and the tenant will be better off.

It is also possible for Operation Barga to have beneficial effects on productivity without making the landlord better off. This will be the case if eviction threats were very effective in eliciting extra effort from the tenant before the reform. Let $R$ denote the rents to the tenant from staying in the relationship in the second period. Under our assumptions, $R=1 / 8 c$. From the analysis of Section III $C$, we know that if eviction threats are used in the first period, then in that period $e=(1+$ $R) / 2 c$ and $r_{h}=(1+R) / 2$. Since the second period is the last period, $e=1 / 2 c$ and $r_{h}=\frac{1}{2}$ as in the static model. The landlord's total expected profit is $\left[(1+R)^{2} / 4 c\right]+(1 / 4 c)$. Suppose instead that the landlord guarantees tenure to the tenant and precommits to the second-period contract. In this case, the maximum amount by which the landlord can increase the second-period rent ex ante is equal to the net social surplus from investment, $1 / 2 \gamma$. Hence, his total expected profit is $(1 / 2 c)+$ $(1 / 2 \gamma)$. It is readily checked that if $c$ is low and $\gamma$ is high (which means that it is relatively cheaper to elicit effort from the tenant than invest- 
ment), the landlord will prefer to use eviction as a threat. In this case, even though the legal contract raises investment, efficiency, and the tenant's payoff, the landlord will be worse off.

We can summarize our analysis as follows.

Result 4. An improvement in the tenant's outside option increases the marginal return on contractible investments that are complementary with effort. Security of tenure and a higher crop share induce the tenant to increase the supply of noncontractible land-specific investments.

\section{E. Operation Barga, Security of Tenure, and Crop Shares}

Theoretically we expect Operation Barga to have increased the outside option of tenants and to have made eviction impossible. We know from the aggregate data that the tenants responded positively to the reform: according to official estimates, by 1993, about 65 percent of all sharecroppers were registered, compared to 15 percent before Operation Barga. However, the aggregate data do not indicate whether the reform actually affected contractual terms. In order to fill this gap, we surveyed a stratified random sample of 480 sharecroppers from 48 villages in West Bengal. The survey asked each farmer detailed questions about various aspects of the landlord-tenant contractual relationship before and after the reform. ${ }^{22}$

These data show that the reform greatly improved security of tenure. In the prereform period, tenure was not secure: 74 percent of tenants surveyed said that in the prereform period their leases did not have a specified duration and were subject to arbitrary termination by the landlord, 80 percent reported that landlords in their village had used eviction threats, and 30 percent reported that they or their fathers were actually threatened. ${ }^{23}$ The reasons cited for the use of threats of eviction include both low production (in 40 percent of the cases) and disputes with the landlord (in 55 percent of the cases). In other words, eviction was used both as an incentive device and as an instrument for bargaining. After the reform, eviction threats have almost disappeared: 96 percent of all respondents reported that evicting registered tenants is difficult or impossible, and 67 percent also reported that it is difficult or impossible to evict even unregistered tenants-largely because they can register themselves whenever they want. Finally, actual evictions in the postreform period are rare: only 30 percent of respondents said that they know of a tenant who was evicted in the last 10 years.

Since eviction threats were used by the landlord in bargaining in the

${ }^{22}$ See Banerjee and Ghatak (1996) for a more detailed discussion of the survey.

${ }^{23}$ These numbers presumably understate the importance of these threats since in equilibrium the tenants presumably adjust their behavior to avoid the threats. 


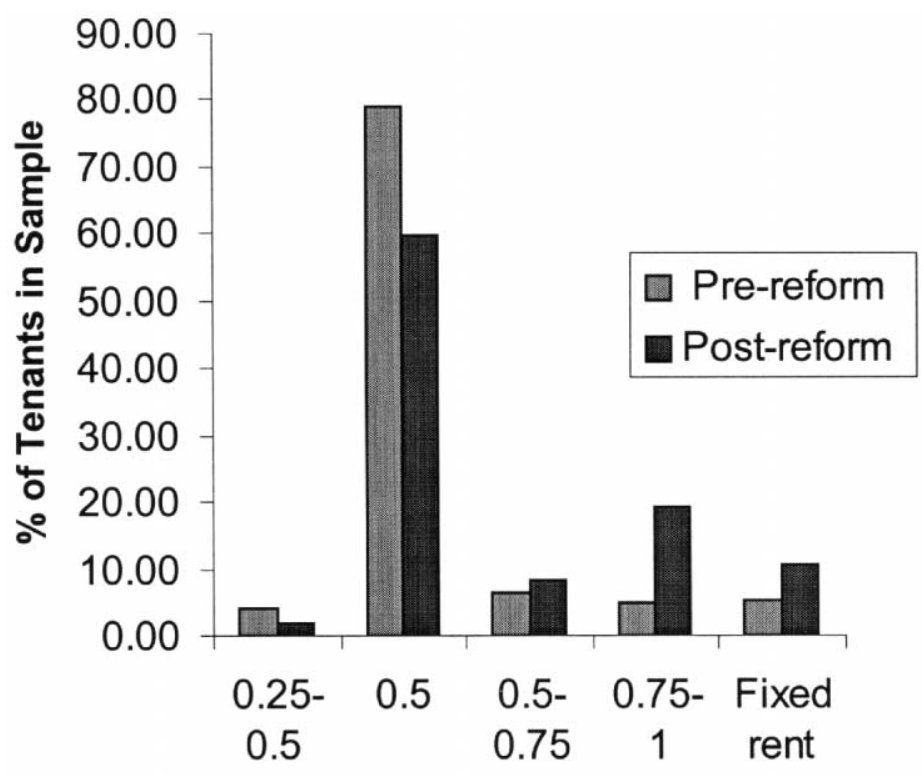

Tenant's Crop Share

FIG. 3.-Crop share of tenants before and after the reform

prereform period, making eviction difficult or impossible must have strengthened the tenant's bargaining position: in other words, $m$ should have gone up. Our model says that the tenant's share of the crop should go up, or at least not go down, when $m$ goes up. Our survey (as well as smaller surveys by Kohli [1987] and Chadha and Bhaumik [1992]) confirms that crop shares increased after the reform (see fig. 3). For example, the proportion of tenants in our sample getting more than 50 percent of output increased from 17 percent to 39 percent. Evidence from our survey suggests that while shares rose for both registered and unregistered tenants, the increase was greater for registered tenants. To the extent that unregistered tenants faced some insecurity of tenure, their bargaining power presumably increased less, resulting in a smaller increase in the share. ${ }^{24}$

${ }^{24}$ This begs the question of why these tenants did not register. Unregistered tenants in our sample cited two main reasons for not registering: either they had good relations with the landlord or they were dependent on the landlord for credit or other inputs. We might surmise that for both these groups, though for different reasons, the change in $m$ was more limited than it was for those who registered. 
This evidence, however, underestimates the extent of change in shares. We were able to survey only those who were still tenants in 1995. This leaves out all those who switched from being sharecroppers to being owner-farmers as a result of the program. This happened for two reasons. First, many landlords, especially those who were absentee, faced with having to deal with a registered sharecropper, preferred to sell out and leave. As a result, land prices fell, allowing erstwhile sharecroppers to buy land. Second, even in cases in which the landlord did not sell out and leave, he often preferred to arrive at an arrangement with his tenant whereby the tenant received ownership of a part of the land in return for giving up his claim on the rest. ${ }^{25}$ In a detailed study of the land market in two villages in West Bengal, Rawal (2001) found that between 1977 and 1995, an amount of land constituting over 30 percent of total cultivated area was sold. The major sellers were large or absentee landowners, and the major purchasers were small owner-cultivators and sharecroppers. This is in sharp contrast with other Indian states, where land markets are very thin. To the extent that any land transfer takes place, it occurs from smaller to larger landowners.

\section{F. Discussion}

Eliminating the possibility of eviction reduces effort and other noncontractible current inputs as long as $m$ is held fixed in our model. However, once the possibility of eviction is eliminated, a higher $m$ tends to increase the supply of these inputs. Since Operation Barga both eliminated evictions and increased $m$, its net effect could be positive or negative. There are several other reasons why we might expect the net effect of the reform to be positive. First, investment incentives improve with better security of tenure. Second, our survey indicates that before the reform, eviction threats were not commonly used to punish tenants for producing too little. ${ }^{26}$ Third, if the negative incentive effect was indeed significant for some tenant, the landlord could make him a side payment and sell off the land to an owner-farmer (or cultivate it himself). Indeed, such sales were part of the post-Operation Barga scene. Finally, the reform could have had indirect effects that go beyond the contractual relationship between landlords and tenants, something that we have not formally analyzed here. Some commentators (e.g., Gazdar and Sengupta

\footnotetext{
${ }^{25}$ This is in fact what our model would have predicted if we had allowed the landlord to own several plots of land and self-cultivation by the landlord was an option. Our survey and other studies (Rawal 2001) have found several instances of such land transfers.

${ }^{26}$ Recall that only 40 percent of the 30 percent (i.e., 12 percent of the entire sample) of tenants who indicated that they or their father was threatened with eviction singled out this particular reason. Of course, as pointed out above, these numbers probably underestimate the importance of threats of eviction.
} 
1999) have put particular emphasis on this indirect effect of agrarian reform in West Bengal. It is often argued (see Boyce 1987) that collective action within rural societies (e.g., with respect to management of irrigation water) is severely handicapped by the extreme inequality in the distribution of political and economic power within the society. To the extent that Operation Barga affected this distribution of power, it is likely to have contributed to the alleviation of such collective action problems. ${ }^{27}$

\section{Evidence: The Effect of Operation Barga on Productivity}

Our objective in this section is to estimate the effect of the change in property rights brought about by Operation Barga on agricultural productivity in West Bengal. We take two approaches. The first is a quasiexperimental approach that uses Bangladesh as a control. The second uses the number of registered sharecroppers in a district as a measure of program intensity and compares the growth in productivity in districts in which Operation Barga was implemented intensely to districts in which the program was implemented less intensely.

\section{A. Comparison to Bangladesh}

Bangladesh, which did not introduce tenancy reform, provides a good comparison to West Bengal. Prior to independence, Bangladesh and West Bengal were parts of the same state in undivided India. Except for religion and political boundaries, the two regions are very similar in most respects. This includes agroclimatic conditions, prevalence of tenancy, and agricultural technology (Boyce 1987). Hence we can expect technological shocks to agricultural yields to be similar between these two regions.

The fact that Operation Barga was implemented in West Bengal but not in Bangladesh can be largely attributed to an exogenous shock. Operation Barga could be implemented only because a left-wing government unexpectedly came into power in West Bengal in 1977. This was a result of a nationwide wave against the Congress Party, which had ruled in most states since independence. In the mid 1970s, a severe political crisis led the Congress-dominated central government to suspend civil liberties. In the subsequent elections in 1977, the voters punished the Congress Party for this: the Left in West Bengal was the beneficiary of this anti-Congress wave. Thus the timing of Operation Barga

\footnotetext{
${ }^{27}$ See Bardhan, Ghatak, and Karaivanov (2002) for a theoretical analysis of how lower land inequality can improve overall efficiency in the presence of collective action problems ranging from the provision of public goods to the use of common property resources.
} 


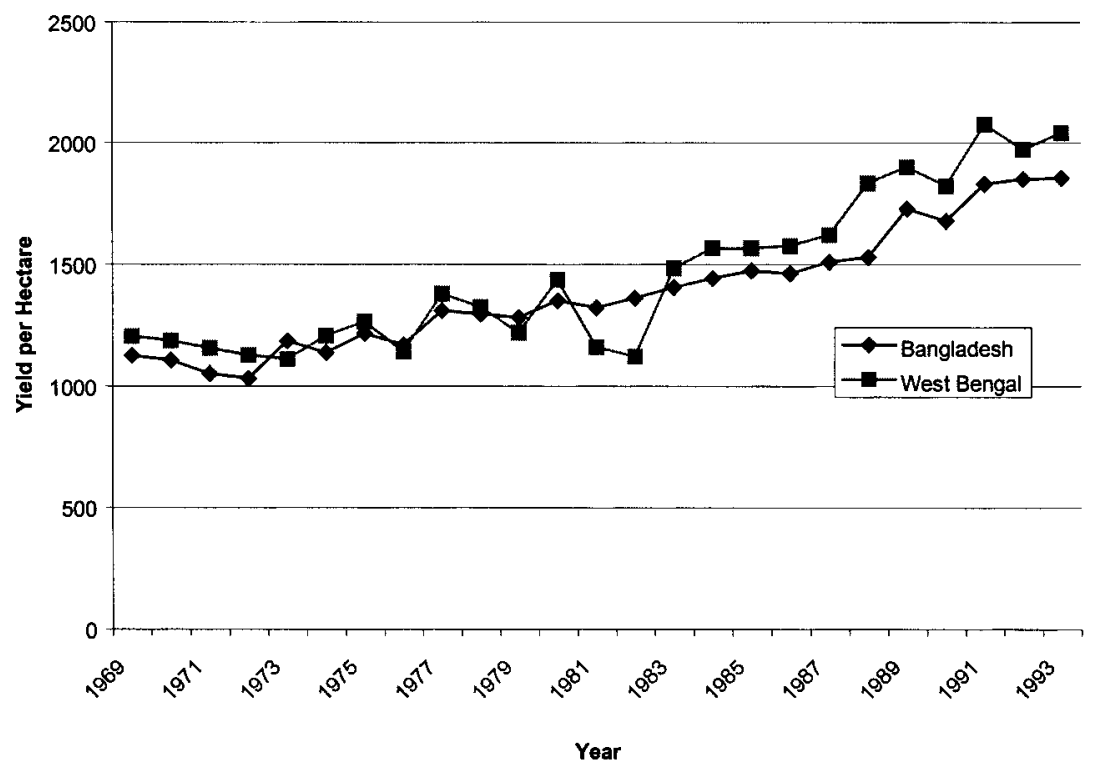

Fig. 4.-Rice yield in West Bengal and Bangladesh, 1969-93

did not reflect what was then happening in West Bengal but rather what was happening in the rest of India.

In the period before Operation Barga, agricultural productivity was growing at almost identical rates in the two states. Rice is the main component of agricultural production in West Bengal and Bangladesh and is planted in over 70 percent of cropped area. Between 1969 and 1978, a period covering the decade before Operation Barga, rice yields increased by 9.3 percent in West Bengal and by 11 percent in Bangladesh. In the period after Operation Barga was introduced (1979-93), rice yields in West Bengal increased by 69 percent compared to 44 percent in Bangladesh. ${ }^{28}$ This can be seen more clearly in figure 4 , which presents rice yields per hectare over time for West Bengal and Bangladesh. Until 1979, the first real year of Operation Barga, rice yields are approximately the same for the two countries. In the post-Operation Barga period, rice yields in West Bengal are substantially higher in all years except for 1981 and 1982, when West Bengal experienced two

${ }^{28}$ The average exponential rate of growth per year was 4.1 percent in West Bengal and 2.7 percent in Bangladesh during 1979-93. See Saha and Swaminathan (1994) for a detailed analysis of the growth performance of agriculture in West Bengal during this period. 
successive years of severe droughts, among the worst experienced in the century (Government of West Bengal Economic Review, 1983, pp. 1314). ${ }^{29}$

During the period of study, agricultural productivity in both regions (and much of eastern India) grew in part as a result of three common factors: the belated arrival of the Green Revolution permitted by the spread of a locally suited high yield variety (HYV) of rice, a fall in the price of fertilizers, and an increase in small-scale private irrigation (Harriss 1993). However, even though the rate of adoption of HYV rice was faster in Bangladesh than in West Bengal, the rate of growth in rice productivity was higher in West Bengal. This difference is what we shall attribute to the implementation of Operation Barga.

\section{Methods}

We measure the impact of Operation Barga on agricultural rice yields using a difference-in-difference estimator with district-level panel data. The difference-in-difference specification compares the change (before and after Operation Barga) in yields in treatment districts (West Bengal) with the corresponding change in control districts (Bangladesh).

The difference-in-difference model can be specified in regression form as

$$
\ln y_{d t}=\alpha_{d}+\psi_{t}+\beta \times \text { treatment }_{d} \times \text { post }_{t}+\sum \phi_{j} X_{j d t}+\epsilon_{d t} .
$$

The dependent variable is the log of the rice yield per hectare in district $d$ and year $t$. The right-hand-side variables include a fixed effect for each district, a fixed effect for each year, the interaction of a variable indicating whether the district is a treatment (i.e., in West Bengal), and an indicator of whether it is the postreform period. There are also a series of control variables (the $X_{j}^{\prime}$ 's) that vary over time and across districts. The district fixed effects control for district-specific factors that are fixed over time, and the year fixed effects control for factors that vary over time but are common across all districts-both treatment and control. The coefficient $\beta$ is the difference-in-difference estimate of the impact of Operation Barga on rice yields.

The difference-in-difference model makes the counterfactual assumption that the treatment districts would grow at the same rate as

\footnotetext{
${ }^{29}$ Agriculture in South Asia is heavily dependent on the summer monsoon rains, whose distribution over time and across regions tends to be highly variable (see Das 1995, pp. 228-34). While crop yields depend on the total amount and timing of rainfall, we are able to control for only the former. These two years had lower than average total rainfall for both West Bengal and Bangladesh, but crop production in West Bengal (especially the main variety of rice, aman) additionally suffered from the erratic timing of the monsoons.
} 
the control districts if there were no intervention. While this assumption is not directly testable, we can test whether the treatment districts and the control districts were growing at the same rate in the preintervention period. If we do find that they were growing at the same rate, it would suggest that our counterfactual assumption is likely to be correct.

This assumption would also be violated if there were some other interventions that were contemporaneous with Operation Barga and were differentially implemented in West Bengal and Bangladesh. To control for the possibility that there were other interventions contemporaneous with Operation Barga that could explain divergence between West Bengal and Bangladesh, we explicitly investigate two important agricultural policies: public irrigation and adoption of HYV grains of rice, which is a measure of the progress of the Green Revolution. These are the interventions that are typically seen as the major technological sources of increased productivity.

\section{Simple Difference-in-Difference Results}

In this subsection we estimate a simple difference-in-difference model with no time-varying controls on log rice yields for the period 1969-93. ${ }^{30}$ The data are district-level data from 14 West Bengal and 15 Bangladesh districts collected from various official government sources. ${ }^{31}$ Summary statistics for the log of rice yields for West Bengal and Bangladesh for this period are reported in column 1 of table 1 .

We begin by testing the hypothesis that growth in yields in West Bengal districts and Bangladesh districts was the same in the pre-Operation Barga period. This is an indirect test of the difference-in-difference assumption that the change in the control districts is what would have happened in the treatment districts if there were no intervention. To conduct the test we regress changes in log yields over the period 1969-78 against an indicator of whether the district is in West Bengal and year dummies. The hypothesis is rejected if the coefficient on the West Bengal dummy is significantly different from zero. The results are presented in column 1 of table 2 . We cannot reject the hypothesis that growth was the same in both control and treatment districts in the pre-Operation Barga period.

The coefficient estimates from the simple difference-in-difference

${ }^{30}$ The data are taken from Economic Review (1969-93); the 1990 Statistical Abstract (Government of West Bengal); and the 1969-93 Statistical Yearbook of Bangladesh (Bangladesh Bureau of Statistics, Statistics Division, Ministry of Planning, Government of the People's Republic of Bangladesh).

${ }^{31}$ From West Bengal we excluded Calcutta, which is almost completely urban, and $\mathrm{Pu}-$ rulia, for which data are not available for a considerable number of years. From Bangladesh we excluded eight districts for which data are not available for a large number of years because of changes in the administrative boundaries of these districts. 
TABLE 1

Summary Statistics

\begin{tabular}{|c|c|c|c|c|c|c|c|}
\hline & \multicolumn{2}{|c|}{$\begin{array}{l}\text { Log(Rice Yield, } \\
\text { kg per Hectare) }\end{array}$} & \multirow{2}{*}{$\begin{array}{l}\text { HYV } \\
\text { SHARE, } \\
1977-93 \\
(3)\end{array}$} & \multirow{2}{*}{$\begin{array}{l}\text { PROPORTION OF } \\
\text { REGISTERED } \\
\text { TENANTS, }^{\mathrm{b}} \\
\text { 1978-92 } \\
\text { (4) }\end{array}$} & \multirow{2}{*}{$\begin{array}{c}\text { Log(Area } \\
\text { under Public Irri- } \\
\text { gation, } \\
\text { Hectare), } \\
1977-93 \\
\text { (5) }\end{array}$} & \multirow{2}{*}{$\begin{array}{c}\log (\text { Road Length, } \\
\mathrm{km}){ }^{\mathrm{d}} \\
1977-93 \\
(6)\end{array}$} & \multirow{2}{*}{$\begin{array}{c}\log (\text { Rainfall, } \\
\text { mm) } \\
1977-93 \\
(7)\end{array}$} \\
\hline & $\begin{array}{l}1969-93 \\
\text { (1) }\end{array}$ & $\begin{array}{l}1977-93 \\
(2)\end{array}$ & & & & & \\
\hline & \multicolumn{7}{|c|}{ West Bengal (Annual Observations on 14 Districts) } \\
\hline Grand mean & 7.24 & 7.32 & .11 & .49 & 10.01 & 6.99 & 7.42 \\
\hline \multicolumn{8}{|l|}{ Standard deviation: } \\
\hline Overall & .31 & .31 & .09 & .23 & 1.80 & .39 & .41 \\
\hline Within & .23 & .22 & .05 & .18 & .30 & .07 & .24 \\
\hline \multicolumn{8}{|l|}{ Mean in: } \\
\hline 1969 & 7.06 & & & $\ldots$ & & & \\
\hline 1977 & 7.20 & 7.20 & .06 & $\ldots$ & 9.91 & 6.93 & 7.24 \\
\hline 1979 & 7.07 & 7.07 & .06 & .15 & 9.92 & 6.94 & 7.17 \\
\hline \multirow[t]{2}{*}{1993} & 7.60 & 7.60 & .18 & .65 & 10.13 & 7.02 & 7.58 \\
\hline & \multicolumn{7}{|c|}{ Bangladesh (Annual Observations on 15 Districts) } \\
\hline Grand mean & 7.22 & 7.30 & .15 & 0 & 11.36 & $\ldots$ & 7.69 \\
\hline Standard deviation: & & & & & & & \\
\hline Overall & .23 & .20 & .11 & 0 & .89 & $\ldots$ & .35 \\
\hline Within & .19 & .15 & .07 & 0 & .43 & $\ldots$ & .21 \\
\hline \multicolumn{8}{|l|}{ Mean in: } \\
\hline 1969 & 7.05 & & & & $\cdots$ & $\ldots$ & \\
\hline 1977 & 7.16 & 7.16 & .09 & 0 & 11.00 & $\ldots$ & 7.62 \\
\hline 1979 & 7.14 & 7.14 & .09 & 0 & 11.06 & $\ldots$ & 7.64 \\
\hline 1993 & 7.51 & 7.51 & $.25^{\mathrm{e}}$ & 0 & 11.76 & $\ldots$ & 7.84 \\
\hline
\end{tabular}

${ }^{b}$ Registration data are relevant only for West Bengal and are available for the period 1978-93.

c Public minor irrigation schemes include shallow tube wells, deep tube wells, and river lift irrigation.

"This information is not available as a continuous series for Bangladesh during the period of analysis.

"Information on HYV share for Bangladesh is available up to 1991, so this number pertains to 1991. 
TABLE 2

Difference-in-Difference Models of Log of Rice Yield per Hectare (1969-93)

\begin{tabular}{|c|c|c|c|}
\hline & \multirow{2}{*}{$\begin{array}{c}\text { DIFFERENCE } \\
(1969-78) \\
(1)\end{array}$} & \multicolumn{2}{|c|}{ LEVEL } \\
\hline & & $\begin{array}{c}1969-93 \\
(2)\end{array}$ & $\underset{(3)}{\text { Excluding } 1981-82}$ \\
\hline $\begin{array}{l}\text { West Bengal } \\
\quad(=1)\end{array}$ & $\begin{array}{l}.004 \\
(.17)\end{array}$ & $\ldots$ & $\ldots$ \\
\hline $\begin{array}{l}\text { West Bengal } \times \\
\quad(1979-83)^{\mathrm{a}}\end{array}$ & $\ldots$ & $\begin{array}{l}-.09 * * * \\
(3.75)\end{array}$ & $\begin{array}{l}-.01 \\
(.38)\end{array}$ \\
\hline $\begin{array}{c}\text { West Bengal } \times \\
(1984-88)\end{array}$ & $\ldots$ & $\begin{array}{l}.05^{* *} \\
(1.99)\end{array}$ & $\begin{array}{l}.05^{* * *} \\
(2.00)\end{array}$ \\
\hline $\begin{array}{l}\text { West Bengal } \times \\
\quad(1988-93)\end{array}$ & $\ldots$ & $\begin{array}{r}.05^{*} \\
(1.77)\end{array}$ & $\begin{array}{r}.05^{*} \\
(1.78)\end{array}$ \\
\hline $\begin{array}{l}\text { District fixed } \\
\text { effects } F- \\
\text { statistic }\end{array}$ & $\ldots$ & 44.55 & 42.61 \\
\hline $\begin{array}{l}\text { Year fixed ef- } \\
\text { fects } F \\
\text { statistic }\end{array}$ & $4.26 * * *$ & $29.75 * * *$ & $31.81 * * *$ \\
\hline$R^{2}$ & .12 & .80 & .81 \\
\hline Sample size & 256 & 717 & 659 \\
\hline
\end{tabular}

models of $\log$ rice yield are presented in columns 2 and 3 of table 2 for 1969-93. The key variables are the interactions of an indicator of whether the district is in the treatment area (West Bengal) with indicators of whether the year was in the postreform period. We split the postreform period into three periods of equal length to accommodate variation in the speed at which registration proceeded, as well as lags in the output response to Operation Barga (e.g., because the effect through increased investment would take time to materialize). The last period reflects the full effect of Operation Barga since registration was mostly complete by then and any resulting investments are likely to have already affected productivity. We reestimated the model excluding 1981 and 1982, when West Bengal experienced two successive years of major droughts.

The first three coefficients in columns 2 and 3 are the difference-indifference estimates. In the early years of Operation Barga (1979-83), West Bengal grew slower than Bangladesh, but this effect seems to be entirely driven by the presence of the two drought years that disproportionately affected West Bengal. In the next two periods (1984-88 and 1988-93), rice yields were about 5 percent higher. These results are consistent with the hypothesis that Operation Barga had a positive impact on productivity. 


\section{Adjusted Difference-in-Difference Results}

In this subsection, we adjust the simple difference-in-difference estimates for time-varying controls. However, the data on the time-varying controls exist only for the period 1977-91 for both Bangladesh and West Bengal. The data available for both regions include information on rice production and average yield per hectare, a measure of the amount of rice area under HYV cultivation, ${ }^{32}$ total annual rainfall, and area covered by public irrigation. Descriptive statistics for these data are reported in table 1. We see that in the postreform period (1979-93), the share of HYV rice in total cultivated area increased from 6 to 18 percent in West Bengal and went up from 9 to 25 percent in Bangladesh. Over the same period, area under public irrigation increased by 23 percent in West Bengal and doubled in Bangladesh. ${ }^{33}$

The availability of data on time-varying controls allowed us to estimate a number of different specifications to test the robustness of the estimates. ${ }^{34}$ The results of this exercise are reported in table 3 . We estimated a simple unadjusted difference-in-difference model (model 1), another controlling for public irrigation and rainfall (model 2), and another that additionally controlled for HYV share (model 3).

The models show that, except for the first period, rice yields grew faster in West Bengal than in Bangladesh and the differentials grow over time. Model 1, which repeats the simple difference-in-difference analysis for the shorter panel, yields results similar to the simple difference-indifference results for the long panel reported in the previous subsection. When the drought years are excluded, there is no difference between West Bengal and Bangladesh in the early period, 1979-83. The differential in the later periods (1984-87 and 1988-91) grows when timevarying controls are included in the model. When we control for rainfall, public irrigation, and HYV share, the West Bengal yields are estimated to be 7 percent higher between 1984 and 1987 and 18 percent higher between 1988 and 1991 .

These estimated differences are an average of sharecropper and owner-cultivator yields. Assuming that Operation Barga had no effect

\footnotetext{
${ }^{32}$ Our measure of HYV adoption is the fraction of total rice area devoted to the cultivation of the summer crop, boro, which is completely dependent on irrigation and uses HYV seeds and other modern inputs.

${ }^{33}$ Data on private irrigation in West Bengal are unfortunately available for only two years within the period under study.

${ }^{34}$ We repeated the test whether the growth rates of the two regions were the same in the prereform period with the controls for this shorter series (for which the prereform period consists of only 1977 and 1978) and again found the West Bengal dummy to be negative and insignificant.
} 
TABLE 3

DifferenCe-IN-Difference Models of Log of Rice Yield (1977-91)

\begin{tabular}{|c|c|c|c|c|c|c|}
\hline & \multicolumn{3}{|c|}{ Whole Sample } & \multicolumn{3}{|c|}{$\begin{array}{c}\text { EXCLUDING DROUGHT YeARS } \\
1981-82\end{array}$} \\
\hline & Model 1 & Model 2 & Model 3 & Model 1 & Model 2 & Model 3 \\
\hline $\begin{array}{l}\text { West Bengal } \times \\
\quad(1979-83)\end{array}$ & $\begin{array}{l}-.08^{* * *} \\
(-2.43)\end{array}$ & $\begin{array}{l}-.07 * * \\
(-2.05)\end{array}$ & $\begin{array}{c}-.05 \\
(-1.58)\end{array}$ & $\begin{array}{l}.001 \\
(.01)\end{array}$ & $\begin{array}{l}.002 \\
(.06)\end{array}$ & $\begin{array}{l}.015 \\
(.47)\end{array}$ \\
\hline $\begin{array}{l}\text { West Bengal } \times \\
\quad(1984-87)\end{array}$ & $\begin{array}{c}.04 \\
(1.17)\end{array}$ & $\begin{array}{c}.05 \\
(1.47)\end{array}$ & $\begin{array}{l}.07 * * \\
(2.04)\end{array}$ & $\begin{array}{c}.04 \\
(1.24)\end{array}$ & $\begin{array}{c}.04 \\
(1.26)\end{array}$ & $\begin{array}{l}.06^{* *} \\
(1.93)\end{array}$ \\
\hline $\begin{array}{l}\text { West Bengal } \times \\
\quad(1988-91)\end{array}$ & $\begin{array}{l}.08^{* *} \\
(2.20)\end{array}$ & $\begin{array}{l}.12 * * * \\
(3.28)\end{array}$ & $\begin{array}{l}.18^{* * *} \\
(5.11)\end{array}$ & $\begin{array}{l}.07 * * \\
(2.33)\end{array}$ & $\begin{array}{l}.11 * * * \\
(2.97)\end{array}$ & $\begin{array}{l}.17 * * * \\
(4.95)\end{array}$ \\
\hline $\log ($ rainfall $)$ & $\ldots$ & $.01(.40)$ & $\begin{array}{l}.007 \\
(.32)\end{array}$ & $\ldots$ & $\begin{array}{l}.019 \\
(.70)\end{array}$ & $\begin{array}{l}.01 \\
(.46)\end{array}$ \\
\hline $\begin{array}{l}\text { Log(public } \\
\text { irrigation) }\end{array}$ & $\ldots$ & $\begin{array}{l}.122^{* * * *} \\
(7.22)\end{array}$ & $\begin{array}{l}.07 * * * \\
(4.27)\end{array}$ & $\ldots$ & $\begin{array}{r}.103 \\
(5.77)\end{array}$ & $\begin{array}{l}.04 * * * \\
(2.69)\end{array}$ \\
\hline $\begin{array}{l}\text { HYV share of } \\
\text { grain cultivation } \\
\text { area }\end{array}$ & $\cdots$ & $\cdots$ & $\begin{array}{l}1.04 * * * \\
(8.18)\end{array}$ & $\ldots$ & $\ldots$ & $\begin{array}{l}1.05^{* * * *} \\
(8.21)\end{array}$ \\
\hline $\begin{array}{l}\text { District fixed } \\
\text { effects } F \text {-statistic }\end{array}$ & $40.02 * * *$ & $20.14^{* * * *}$ & $14.76^{* * * *}$ & $41.43^{* * *}$ & $18.8 * * *$ & $14.64 * * *$ \\
\hline $\begin{array}{l}\text { Year fixed } \\
\quad \text { effects } F \text {-statistic }\end{array}$ & $20.18^{* * * *}$ & $12.14 * * *$ & $7.73 * * *$ & $21.67 * * *$ & $12.41 * * *$ & $6.04^{* * * *}$ \\
\hline$R^{2}$ & .82 & .85 & .87 & .83 & .85 & .88 \\
\hline Sample size & 424 & 424 & 424 & 367 & 367 & 367 \\
\hline
\end{tabular}

on owner-cultivator productivity, we can estimate the effect of Operation Barga on sharecropper productivity using the formula

$$
\frac{1}{A} \frac{d A}{d t}=\frac{s}{1-s} \frac{1}{A^{o}} \frac{d A^{s}}{d t}
$$

where $A$ is average productivity, $A^{o}$ is the average productivity of ownercultivators who are not affected by the reform, $A^{n}$ is the average productivity of sharecroppers, and $s$ is the average area under sharecropping. ${ }^{35}$

There is unfortunately some controversy about the amount of land under sharecropping in West Bengal. The main reasons are lack of reliable land records, the presence of concealed tenancy to evade tenancy laws, and problems of definition of tenancy. Estimates of total cultivated area under sharecropping in West Bengal before the reform were introduced, provided by various rounds of surveys conducted by

${ }^{35}$ This formula follows from taking logs of the equation $A=s A^{n}+(1-s) A^{o}$ using the approximation $\ln (1+x) \simeq x$ when $x$ is small to obtain

$$
\log A_{d}=\frac{s A^{n}}{(1-s) A^{o}}+\log \left[(1-s) A^{o}\right]
$$

and then differentiating with respect to $t$. Notice that these percentage changes occur with respect to productivity in owned land (i.e., $A^{\circ}$ ). Hence the changes with respect to productivity in sharecropped land (i.e., $A^{n}$ ) would be larger. 
the National Sample Survey (NSS), are considered to be the most reliable given their large sample base and methodology. These estimates fall within the range of 18-22 percent (see Bardhan 1976, tables 1, 4). The lower bound of this range, which is obtained from the NSS survey of 1970-71, is considered to be an underestimate (Bardhan 1976; Laxminarayan and Tyagi 1977). The upper-bound estimate obtained from the NSS survey of 1953-54 is considered to be more reliable in this respect because it was conducted before tenancy laws were enacted in the country. We take the estimate of 20 percent, which is at the middle of this range.$^{36}$ Given that total area under rice cultivation in West Bengal is around 70 percent and sharecropping is observed predominantly with respect to rice cultivation, the proportion of rice area under sharecropping is higher. According to a recent study, over 90 percent of land leased by sharecroppers was under rice cultivation (Bhaumik 1993, table 6.2). This gives us an estimate of about a quarter of rice area under sharecropping. ${ }^{37}$

Under the assumption that there was no differential change in the yields of owner-cultivators between West Bengal and Bangladesh, sharecropper productivity increased by 51 percent during the last period $(1988-91) .^{38}$ This period gives us the cumulative effect of the reform (i.e., including the effect through investment).

One striking result that can be seen from table 3 is that the estimate of the impact of Operation Barga on productivity increases when we control for public irrigation and the Green Revolution. This suggests that Bangladesh expanded these public programs faster than West Bengal did in the post-Operation Barga period. This hypothesis is consistent with the descriptive statistics reported in table 1 . We formally test this hypothesis using the difference-in-difference framework with public irrigation and HYV share as the dependent variables. The results are presented in table 4 . The results show that both public irrigation and the share of HYV expanded faster in Bangladesh in the postreform period than they did in West Bengal.

The fact that Bangladesh expanded these public programs designed to improve agricultural productivity faster than West Bengal is important

\footnotetext{
${ }^{36}$ It is also in the middle of the range provided by Boyce (1987, p. 214) in his authoritative study on agriculture in West Bengal and Bangladesh (namely, one-sixth to one-fourth) based on various sources including the NSS.

${ }^{37}$ Official data suggest that the fraction of land under sharecropping that is formally registered is about 8.2 percent of total cultivated area, or 10.5 percent of area devoted to rice cultivation. This number underestimates the total cultivated area on which Operation Barga had a direct effect since it does not take into account the effect on unregistered sharecroppers and transfer of land from sharecropping to owner cultivation due to land sales and transfers. The size of the total area under sharecropping before Operation Barga was introduced is preferred for this reason.

${ }^{38}$ This estimate is obtained by multiplying the coefficient of West Bengal $\times(1988-91)$ reported in table 3 by $(1-s) / s=3$.
} 
TABLE 4

Difference-IN-Difference Models of Other Public Policies (1977-91)

\begin{tabular}{|c|c|c|c|c|}
\hline & \multicolumn{2}{|c|}{ Log(Public Irrigation) } & \multicolumn{2}{|c|}{ HYV SHARE } \\
\hline & Whole Sample & $\begin{array}{c}\text { Excluding } \\
1981-82\end{array}$ & Whole Sample & $\begin{array}{c}\text { Excluding } \\
1981-82\end{array}$ \\
\hline $\begin{array}{c}\text { West Bengal } \times \\
(1979-83)\end{array}$ & $\begin{array}{l}-.24 * * \\
(-2.28)\end{array}$ & $\begin{array}{c}-.18 \\
(-1.61)\end{array}$ & $\begin{array}{l}-.03 * * \\
(-2.25)\end{array}$ & $\begin{array}{r}-.022 \\
(-1.45)\end{array}$ \\
\hline $\begin{array}{c}\text { West Bengal } \times \\
\quad(1984-87)\end{array}$ & $\begin{array}{l}-.27 * * * \\
(-2.44)\end{array}$ & $\begin{array}{l}-.24 * * \\
(-2.18)\end{array}$ & $\begin{array}{l}-.014^{*} \\
(-1.88)\end{array}$ & $\begin{array}{l}-.029 * * \\
(-1.95)\end{array}$ \\
\hline $\begin{array}{l}\text { West Bengal } \times \\
(1988-91)\end{array}$ & $\begin{array}{l}-.57 * * * \\
(-4.97)\end{array}$ & $\begin{array}{l}-.53 * * * \\
(-4.69)\end{array}$ & $\begin{array}{l}-.083^{* * *} \\
(-5.25)\end{array}$ & $\begin{array}{l}-.085^{* * * *} \\
(-5.58)\end{array}$ \\
\hline $\log$ (rainfall) & $\begin{array}{c}.06 \\
(.82)\end{array}$ & $\begin{array}{c}.005 \\
(.06)\end{array}$ & $\begin{array}{c}.006 \\
(.56)\end{array}$ & $\begin{array}{c}.007 \\
(.67)\end{array}$ \\
\hline $\begin{array}{l}\text { District fixed } \\
\text { effects } F- \\
\text { statistic }\end{array}$ & $250.66 * * *$ & $227.98 * * *$ & $55.32 * * *$ & $49.21 * * *$ \\
\hline $\begin{array}{l}\text { Year fixed ef- } \\
\text { fects } F- \\
\text { statistic }\end{array}$ & $8.68 * * *$ & $9.51 * * *$ & $29.65 * * *$ & $31.22 * * *$ \\
\hline$R^{2}$ & .96 & .96 & .85 & .85 \\
\hline Sample size & 424 & 367 & 424 & 367 \\
\hline
\end{tabular}

for interpreting the results. A concern with this methodology is that there may be unobserved differences in government programs between the two countries. If these unobserved programs behaved like the observed programs and also expanded faster in Bangladesh in the post-Operation Barga period, our difference-in-difference estimates of the impact of Operation Barga on agricultural productivity would give us a lower-bound estimate. However, we cannot completely rule out the possibility that there were unobservable policies that confound the estimated effect. We therefore complement this analysis with an alternative approach in which we estimate the effect of Operation Barga using variation in program intensity across districts within West Bengal. ${ }^{39}$

\section{B. Program Intensity}

The approach taken in this subsection uses the district sharecropper registration rate as a measure of program intensity and then examines whether productivity rises faster in areas with greater program intensity.

\footnotetext{
${ }^{39}$ Some changes were introduced in the methodology of collection of official crop statistics in West Bengal starting in 1986 that, according to some critics, could result in biased estimates of the growth rate. When interdistrict variation in program intensity within West Bengal is used to estimate the effect of Operation Barga, our second approach is not subject to any possible bias resulting from this source.
} 
We have data on the number of registered tenants in West Bengal for the period 1978-93, with 1978 being the year in which Operation Barga was launched. ${ }^{40}$ Operation Barga was launched in 1978, and at the beginning of 1978, the average level of registration for West Bengal was 15 percent. In 1993, registration stood at 65 percent of the total number of sharecroppers. We augment the set of time-varying controls for West Bengal used in the previous section by data on the length of roads constructed and maintained by the public works department. ${ }^{41}$

We begin by formally deriving the empirical specification, which relates yields to the registration rate and other covariates from the production process. However, we do not have data about the productivity of individual sharecroppers. What we have is district-level yields generated by averaging across registered sharecroppers, unregistered sharecroppers, and owner-cultivators. In order to interpret the coefficients correctly, in the next subsection we aggregate the individual-level model to generate a district-level model.

\section{Specification}

Individual farm productivity.-Our starting point is a reduced-form productivity equation derived from a structural profit-maximizing model of a tenant farmer. Production depends on the tenant's noncontractible inputs (e.g., effort), contractible inputs (e.g., fertilizer and seeds), publicly provided inputs (e.g., irrigation and roads), and rainfall. Farmers choose effort and contractible inputs to maximize profits subject to the agricultural production function, the parameters of the tenancy contract, prices, public inputs, and rainfall. We assume a Cobb-Douglas specification for farm i's profit-maximizing output per hectare (yield) at time $t$ :

$$
Y_{i t}=A\left(\mathbf{c}_{i t}, \boldsymbol{\theta}_{i}\right)\left(\prod_{j=1}^{n} P_{j t}^{\alpha_{j}}\right)\left(\prod_{k=1}^{N} X_{k i t}^{\beta_{k}}\right) r_{i t}^{\gamma}\left[\exp \left(\epsilon_{i t}\right)\right]
$$

where $A$ is the $X$-efficiency of the farm, $\mathbf{c}_{i t}$ is a vector of contract parameters (e.g., crop share, probability of eviction for different values of output, etc.), $\theta_{i}$ represents fixed characteristics of the tenant and the farm (e.g., wealth, ability, and land quality), the $P_{j t}$ are market prices of contractible inputs (we set the output price equal to one), the $X_{k i t}$ are publicly available inputs provided by the government (e.g., canal irri-

\footnotetext{
${ }^{40}$ Data on sharecropper registration were obtained from the Statistical Cell, Department of Land Reforms, Government of West Bengal, and data on districtwise number of sharecroppers from Datta (1981).

${ }^{41}$ These data are not available for Bangladesh after 1984 and hence were not used in the previous subsection.
} 
gation available for the farm and roads for transport of produce to market), $r_{i t}$ is the amount of rainfall on the farm during period $t$, and $\epsilon_{i t}$ is a zero mean random productivity shock.

The change in the $X$-efficiency parameter $A$ captures the net effect of the two contractual responses to the reforms. The first is the effect of improved crop share of tenants on the supply of noncontractible inputs (e.g., effort). The second is the net effect of the permanency of tenure on the choice of inputs (both current inputs and investments).

In Section IIIE, we found that tenants renegotiated their contracts and obtained better terms after they had the opportunity to register even when they did not register. Therefore, we need to account for both types of tenant farmers in the analysis. Let $A^{n}$ denote the efficiency of a tenant farm in the prereform period. Further, let $A^{r}$ and $A^{u}$ denote the efficiency of tenant farms whose contracts were renegotiated after the reform, with the former referring to a farm cultivated by a registered tenant and the latter to a farm cultivated by a tenant who did not register even though he had the opportunity to do so. As pointed out before, the latter category includes both those who remained tenants and those who became owners. Finally, let $A^{o}$ be the efficiency of an owner-cultivated farm, which should be unaffected by the reform.

District productivity.-Since the data on total output are at the district level, we have to aggregate the individual farm productivity model to that level. This requires aggregating across registered sharecroppers, unregistered sharecroppers, and owner-cultivators. Over time, the number of registered sharecroppers rose and unregistered sharecroppers fell as Operation Barga was implemented.

The reforms reached tenants in the form of opportunities to register with the land bureaucracy. In order for tenancy laws to be enforced, the tenant had to register his status with the Land Revenue Office. Land revenue officials went village by village to create and update tenancy registration. The government, however, could not make the opportunity to register available to all tenants at the same time within and across districts because of resource constraints and logistical problems. Instead, registration opportunities expanded through districts over time on a village-by-village basis.

Therefore, average district $X$-efficiency at any point in time depends on the proportion of farmers who were tenants, the proportion of tenants who had the opportunity to register, and the proportion of people who chose to register (henceforth, the take-up rate). Because it would take some time for the parties to renegotiate the contracts and for that to have an effect on yields, especially through investment incentives, we use the proportion of tenants who had the opportunity to register lagged 
by one period..$^{42}$ Formally, let $s_{d}$ be the share of land that is cultivated by sharecroppers in district $d, v_{d t}$ be the share of sharecroppers who have been offered the opportunity to register in district $d$ at time $t$, and $\lambda_{d}$ be the take-up rate. Then the average $X$-efficiency of district $d$ in period $t$ is

$$
A_{d t}=s_{d}\left\{v_{d t-1}\left[\lambda_{d} A^{r}+\left(1-\lambda_{d}\right) A^{u}\right]+\left(1-v_{d t-1}\right) A^{n}\right\}+\left(1-s_{d}\right) A^{o} .
$$

In principle, we would like to identify the effect of the reform by examining the effect of registration opportunities on district-level productivity. However, there is no information on the proportion of tenants who were offered such opportunities. We shall therefore use time-specific information on the proportion of tenants who actually registered as a proxy for the share of those who were offered registration opportunities. We rewrite (10) in terms of the proportion of tenants who have registered, $b_{d t-1}=\lambda_{d} v_{d t-1}$, to get

$$
A_{d t}=s_{d}\left[b_{d t-1}\left(A^{r}+\frac{1-\lambda_{d}}{\lambda_{d}} A^{u}-\frac{A^{n}}{\lambda_{d}}\right)+A^{n}\right]+\left(1-s_{d}\right) A^{o} .
$$

Rearranging terms and taking the log, we get

$$
\begin{aligned}
\ln A_{d t}= & \ln \left\{1+\frac{s_{d}}{1-s_{d}} b_{d t-1}\left[\frac{\lambda_{d} A^{r}+\left(1-\lambda_{d}\right) A^{u}-A^{n}}{\lambda_{d} A^{o}}\right]+\frac{s_{d}}{1-s_{d}} \frac{A^{n}}{A^{o}}\right\} \\
& +\ln \left(1-s_{d}\right) A^{o} .
\end{aligned}
$$

Since $\ln (1+x) \simeq x$ when $x$ is small, we rewrite (9) in $\log$ form as

$$
\ln y_{d t}=\alpha_{d}+\gamma b_{d t-1}+\sum_{j} \alpha_{j} \ln P_{j d t}+\sum_{k} \beta_{k} \ln X_{k d t}+\epsilon_{d t}
$$

where

$$
\alpha_{d}=\frac{s_{d}}{1-s_{d}} \frac{A^{n}}{A^{o}}+\ln \left(1-s_{d}\right) A^{o}
$$

and

$$
\gamma=\frac{s_{d}}{1-s_{d}} \frac{\lambda_{d} A^{r}+\left(1-\lambda_{d}\right) A^{u}-A^{n}}{\lambda_{d} A^{o}} .
$$

The coefficient $\gamma$ measures the effect of the reform on agricultural productivity. The numerator of the coefficient is the average $X$-efficiency of sharecroppers offered registration opportunities minus the $X$-efficiency of sharecroppers not offered registration opportunities. This is

\footnotetext{
${ }^{42}$ This would also partially control for the problem that registration could be driven by current productivity shocks. See the next subsection for a detailed discussion of identification problems.
} 
just the marginal increase in productivity arising from registration opportunities. The marginal increase is measured relative to the $X$-efficiency of owner-cultivated farms. The marginal increase is also weighted by one over the take-up rate. This converts the units from change in productivity due to a change in registration opportunities to change in productivity due to a change in the registration rate. ${ }^{43}$

A limitation on the analysis is that districtwise data on output prices and input prices are available only for a limited number of years. Throughout our analysis we include year dummy variables to capture the common movements of prices over time in the districts. This seems to be a reasonable approximation because the state and federal governments control both input and output prices, and hence their movements over time are not very different across districts. ${ }^{44}$ However, to check the robustness of our results, we also estimate the model for the shorter sample for which we have districtwise data on rice prices and real wages. Therefore, the equation to be estimated is

$$
\ln y_{d t}=\alpha_{d}+\psi_{t}+\gamma b_{d t-1}+\sum_{k} \beta_{k} \ln X_{k d t}+\epsilon_{d t}
$$

where $\psi_{t}$ are the year-specific intercepts. Notice that the year fixed effects also control for any other unobserved time-varying factors that are common to districts such as changes in technology or government policies.

\section{Identification}

In this subsection we consider issues relating to the identification of the model. The objective of the exercise is to measure the impact of the reform on agricultural productivity using the registration rate as a measure of program intensity. However, the registration rate may be correlated with unobserved productivity shocks for two reasons. First, the registration rate is a combination of the supply of registration opportunities and the demand for such opportunities. Also, the sequence of villages offered registration was not necessarily chosen at random. Second, the progression of registration opportunities could have been correlated with the progression of other (omitted) programs. The ideal response to these problems would be to use an instrumental variables

\footnotetext{
${ }^{43}$ In principle, $\gamma$ could vary by district if the take-up rates and the relative importance of sharecropping vary by district. However, we do not have long enough time-series variation within districts to estimate district-specific slopes with much precision. Instead, we can estimate the average effect of the reform across all districts. In this case, our specification could be interpreted as a random-coefficients model.

${ }^{44}$ For example, most inputs (e.g., fertilizer, seeds) are distributed by public-sector agencies and subsidized by the federal government. Also the government through various agencies procures a large part of the crop for public distribution, export, and storage purposes.
} 
approach. However, since anything that affects registration is likely to also affect productivity directly, there are no plausible instruments. We therefore take the approach of controlling for a range of time-varying factors that are likely to have influenced productivity. Below we discuss in detail these important issues and how we handle them.

Sources of variation in the registration rate.-The village-by-village visits by land revenue officials to update tenancy registration were a crucial determinant of the registration rate. While it was possible to register at a time other than during a visit, it was much more difficult (Chattopadhyay et al. [1984] and an interview with D. Bandyopadhyay by Maitreesh Ghatak in April 1997). In fact, 76 percent of the registered respondents to our survey of sharecroppers indicated that the official visits with the Land Revenue Office were the single most important factor leading to their registration decision.

The supply of registration opportunities spread at differential rates across districts (Ghosh 1981). ${ }^{45}$ The districts had different bureaucratic resources and physical infrastructures, translating into differential efficiencies of the operation of visits (Ghosh 1981; Chattopadhyay et al. 1984). There were natural shocks to the process of registration such as floods (Lieten 1992). The geographic distribution of sharecroppers within a district varied across districts, and as a result, the marginal cost of making registration opportunities available to tenants varied across districts.

While supply-side frictions explain much of the variation in the registration rate, the distribution of registration opportunities may not have been random. If the government introduced registration opportunities in districts of high or low productivity first, then the registration rate would be correlated with unobserved productivity characteristics and our estimates would be inconsistent. However, if allocations were based on initial productivity, which is a time-invariant factor, the district fixed effects control for this source of bias. On the other hand, if the government dynamically allocated registration opportunities on the basis of current productivity in the district, then the fixed-effects estimate will be biased. A similar problem could occur if the order of villages selected within a district was based on productivity.

While the friction-driven variations in the supply of registration opportunities were clearly important, registration is ultimately a choice. A tenant's decision to register is likely to be affected by his ability, wealth, relations with the landlord, and other characteristics that are associated

\footnotetext{
${ }^{45}$ Information from our survey supports the hypothesis that the supply of opportunities did not arrive at all the villages at the same time. There is a fair amount of variation among villages in terms of peak year of registration. While 1980 had the highest number of villages experiencing peak registration, some villages peaked as late as 1994, 16 years after the launching of the program.
} 
with his dependence on the landlord (e.g., for loans) or his bargaining power. The wealthier, more able, and more enterprising tenants are likely to be more productive and adopt productivity-enhancing technology. These individuals may also be more likely to register. Therefore, a district with a higher proportion of more productive tenants is likely to have high output as well as high registration. However, as long as these individual characteristics are constant over time, they should not be a problem as long as we allow for district fixed effects.

Finally, a portion of registration decisions could be driven by idiosyncratic shocks that vary across time and district. For example, a drought or flood would affect productivity and therefore the decision to register. While we explicitly control for total annual rainfall, there could still be some other district-specific productivity shocks (such as the timing of rainfall) or introduction of new technology that affects the registration choice.

Omitted programs.-Another potential source of bias comes from the possibility that there were public programs that were implemented or strengthened at the same time and in the same locations as Operation Barga. While Operation Barga itself did not provide any other services other than registration opportunities and the enforcement of the tenancy laws, there were clearly other programs that were part of the government's overall reform package. It is not inconceivable that the implementation of these programs was possibly correlated with the implementation of Operation Barga. Below we discuss various alternative programs and to what extent we control for them.

First, there was some expansion of infrastructure in West Bengal. We partially control for public investment in infrastructure by including measures of the availability of public irrigation and roads within districts.

Second, the use of HYV seeds spread during this period (the Green Revolution) spurred partially by government extension programs. We control for this by including the share of gross cropped area planted with HYV seeds.

Third, it is likely that Operation Barga was better implemented in areas in which the Left Front and its peasant organizations have greater political strength. During this period the role of village-level local governments (panchayats) was significantly enhanced in the implementation of various public programs. Operation Barga and other public programs may have been better implemented in districts that had more active local governments, especially those dominated by political parties belonging to the Left Front. To partially control for this, we introduce a Left Front majority district (in 1977) dummy variable interacted with time $^{46}$ as additional controls.

${ }^{46}$ We split the postreform period into three time periods of roughly equal length: 1979-83, 1984-87, and 1988-93. 
Fourth, the south of West Bengal is closer to the administrative center, Calcutta. For this reason, it may have had better access to a range of government programs including Operation Barga. Calcutta being the metropolitan center and the largest city in eastern India, it is possible that districts closer to it would also experience different patterns of market or technological shocks (e.g., people may be more exposed to new ideas or technologies). To control for these possibilities, we introduce the interaction of a southern district dummy variable with time as additional controls.

Fifth, registration may have been targeted toward areas with a high concentration of sharecroppers. This could lead to a spurious correlation if the evolution of population characteristics and opportunities among sharecroppers was different than in the rest of the population. We control for this by including the initial extent of sharecropping interacted with time dummies as additional explanatory variables.

Sixth, there could be some concern that Operation Barga could be picking up some general equilibrium effects on wages and prices. For the limited number of years (1979-87) for which we have districtwise data of wages and prices, we include them as controls to address this issue.

Finally, there are two other programs that we do not explicitly control for but are unlikely to affect our results. The government started a subsidized loan program for registered sharecroppers. However, the program had very limited impact because of bureaucratic limitations (Kohli 1987). Indeed, 87 percent of the respondents to our survey indicated that they never received a loan from either a government or a commercial lending institution. In addition, the administration also redistributed a limited amount of land to the landless and poor peasants. However, most of the redistribution had been completed before the implementation of Operation Barga (Sengupta and Gazdar 1997). Over the entire sample period (1977-93) of our analysis, the land distributed in this manner constituted around 3 percent of the net cropped area of the state.

\section{Results}

Table 5 reports the results for the log rice yield models regressed against the registration rate and controls. Column 1 reports the fixed-effects results with no other controls, and in columns $2-5$ we successively introduce a number of controls. All these models show that the registration rate was significantly positively associated with yields. The other significant coefficient estimates are as expected: expanding roads increases productivity, and rice yields were higher in districts that planted a greater share of HYV grain. In addition, southern districts and those 
TABLE 5

Effect of Registration on the Log of Rice Yield in West Bengal, 1979-93

$(N=210)$

\begin{tabular}{|c|c|c|c|c|c|c|}
\hline & $\begin{array}{l}\text { Model } 1 \\
\text { (1) }\end{array}$ & $\begin{array}{l}\text { Model } 2 \\
\text { (2) }\end{array}$ & $\begin{array}{l}\text { Model } 3 \\
\text { (3) }\end{array}$ & $\begin{array}{l}\text { Model } 4 \\
\text { (4) }\end{array}$ & $\begin{array}{l}\text { Model } 5 \\
\quad(5)\end{array}$ & $\begin{array}{l}\text { Model } 6 \\
\quad(6)\end{array}$ \\
\hline $\begin{array}{l}\text { Sharecropper } \\
\text { registration } \\
\text { (one year } \\
\text { lagged) }\end{array}$ & $\begin{array}{l}.43 * * * \\
(3.46)\end{array}$ & $\begin{array}{l}.42 * * * \\
(3.44)\end{array}$ & $\begin{array}{l}.43 * * * \\
(3.55)\end{array}$ & $\begin{array}{l}.35^{* * * *} \\
(2.69)\end{array}$ & $\begin{array}{l}.36 * * * \\
(2.64)\end{array}$ & $\begin{array}{l}.36^{* * * *} \\
(2.63)\end{array}$ \\
\hline $\log$ (rainfall) & $\ldots$ & $\begin{array}{r}-.07 * \\
(-1.67)\end{array}$ & $\begin{array}{r}-.08^{*} \\
(-1.82)\end{array}$ & $\begin{array}{c}-.07 \\
(-1.59)\end{array}$ & $\begin{array}{r}-.08^{*} \\
(-1.74)\end{array}$ & $\begin{array}{r}-.08^{*} \\
(-1.77)\end{array}$ \\
\hline $\begin{array}{l}\log (\text { public } \\
\quad \text { irrigation })\end{array}$ & $\ldots$ & $\begin{array}{c}.02 \\
(1.01)\end{array}$ & $\begin{array}{l}.01 \\
(.70)\end{array}$ & $\begin{array}{l}.01 \\
(.60)\end{array}$ & $\begin{array}{l}.02 \\
(.83)\end{array}$ & $\begin{array}{l}.02 \\
(.79)\end{array}$ \\
\hline Log(roads) & $\ldots$ & $\begin{array}{l}.28 * * * \\
(2.75)\end{array}$ & $\begin{array}{l}.25^{* *} \\
(2.46)\end{array}$ & $\begin{array}{l}.21^{* * *} \\
(1.99)\end{array}$ & $\begin{array}{c}.19 \\
(1.55)\end{array}$ & $\begin{array}{c}.22 \\
(1.54)\end{array}$ \\
\hline $\begin{array}{l}\text { HYV share of } \\
\text { rice area } \\
F \text {-statistic. }\end{array}$ & $\ldots$ & $\ldots$ & $\begin{array}{l}.57 * * * \\
(2.85)\end{array}$ & $\begin{array}{l}.45^{* *} \\
(2.10)\end{array}$ & $\begin{array}{l}.47 * * \\
(2.16)\end{array}$ & $\begin{array}{l}.47^{* * *} \\
(2.16)\end{array}$ \\
\hline $\begin{array}{l}\text { South } \times \text { year } \\
\text { Left Front } \times\end{array}$ & $\ldots$ & $\ldots$ & $\ldots$ & $4.73 * * *$ & $4.36^{* * * *}$ & $4.38 * * *$ \\
\hline $\begin{array}{l}\text { year } \\
\text { Sharecropping }\end{array}$ & $\ldots$ & $\ldots$ & $\ldots$ & $\ldots$ & $2.64^{* * *}$ & $2.65^{* * *}$ \\
\hline $\begin{array}{l}\times \text { year }^{\mathrm{c}} \\
\text { District fixed }\end{array}$ & $\ldots$ & $\ldots$ & $\ldots$ & $\ldots$ & $2.64^{* * *}$ & .12 \\
\hline $\begin{array}{c}\text { effects } \\
\text { Year fixed } \\
\text { effects }\end{array}$ & $28.31 * * *$ & $27.67 * * *$ & $21.60 * * *$ & $17.63 * * *$ & $17.83 * * *$ & $12.17 * * *$ \\
\hline$R^{2}$ & .91 & .92 & .92 & .92 & .92 & .92 \\
\hline $\begin{array}{l}{ }^{\text {a }} \text { Represents a set } \\
\text { southern West Beng. } \\
\text { b Represents a set } \\
\text { a Left Front majorit } \\
\text { 'Represents a set } \\
\text { * Significant at th } \\
\text { ** Significant at } \\
\text { *** S }\end{array}$ & les o & $\begin{array}{l}\text { by in } \\
\text { ernm } \\
\text { by int }\end{array}$ & $\begin{array}{l}\text { dum } \\
7 \text { wit } \\
\text { he ini }\end{array}$ & $\begin{array}{l}\text { that tak } \\
\text { f sharec }\end{array}$ & $\begin{array}{l}\text { value on } \\
\mathrm{g} \text { in a dis }\end{array}$ & $\begin{array}{l}\text { t distric } \\
\text { th each }\end{array}$ \\
\hline
\end{tabular}

with a Left Front majority in 1977 grew significantly faster. In table 6 we present the results with wages and prices as additional controls for the shorter sample (1979-87). We find that they do not matter significantly directly, or for the estimated coefficients of other right-hand-side variables including registration as long as we control for year-specific shocks.

The magnitude of the effect of Operation Barga on productivity is estimated by multiplying the coefficient on the registration rate with the change in registration over the period. For the full sample, in the model that includes the full set of controls (model 5 of table 5), the fixed-effects estimate is that Operation Barga raised average productivity of rice in West Bengal by 20 percent. ${ }^{47}$ Since rice yields increase by 69

\footnotetext{
${ }^{47}$ Since at the beginning of the program the take-up rate was 15 percent and at the end of it was 65 percent, the take-up rate due to Operation Barga is $(0.65-0.15) /(1-$
} 
TABLE 6

Effect of Registration on the Log of Rice Yield in West Bengal, 1979-87 $(N=126)$

\begin{tabular}{|c|c|c|c|c|c|c|}
\hline & $\begin{array}{l}\text { Model } \\
\text { la }\end{array}$ & $\begin{array}{l}\text { Model } \\
\text { 1b }\end{array}$ & $\begin{array}{l}\text { Model } \\
2 \mathrm{a}\end{array}$ & $\begin{array}{l}\text { Model } \\
2 b\end{array}$ & $\begin{array}{c}\text { Model } \\
3 \mathrm{a}\end{array}$ & $\begin{array}{l}\text { Model } \\
3 \mathrm{~b}\end{array}$ \\
\hline $\begin{array}{l}\text { Sharecropper } \\
\text { registration }\end{array}$ & $\begin{array}{l}.44 * * * \\
(2.71)\end{array}$ & $\begin{array}{l}.46^{* * * *} \\
(2.73)\end{array}$ & $\begin{array}{l}.46^{* * * *} \\
(2.41)\end{array}$ & $\begin{array}{l}.48 * * * \\
(2.89)\end{array}$ & $\begin{array}{l}.40 * * \\
(2.34)\end{array}$ & $\begin{array}{l}.41 * * \\
(2.29)\end{array}$ \\
\hline $\log$ (real wages) & $\ldots$ & $\begin{array}{c}.11 \\
(1.07)\end{array}$ & $\ldots$ & $\begin{array}{l}.05 \\
(.55)\end{array}$ & $\ldots$ & $\begin{array}{l}.03 \\
(.31)\end{array}$ \\
\hline $\begin{array}{l}\log \text { (price of } \\
\text { rice) }\end{array}$ & $\ldots$ & $\begin{array}{l}-.11 \\
(-.98)\end{array}$ & $\ldots$ & $\begin{array}{l}-.04 \\
(-.40)\end{array}$ & $\ldots$ & $\begin{array}{l}.001 \\
(.01)\end{array}$ \\
\hline $\log$ (rainfall) & $\ldots$ & $\ldots$ & $\begin{array}{r}-.08^{*} \\
(-1.65)\end{array}$ & $\begin{array}{c}-.08 \\
(-1.52)\end{array}$ & $\begin{array}{c}-.08 \\
(-1.45)\end{array}$ & $\begin{array}{c}-.08 \\
(-1.41)\end{array}$ \\
\hline $\begin{array}{l}\log \text { (public } \\
\text { irrigation) }\end{array}$ & $\ldots$ & $\ldots$ & $\begin{array}{l}.10^{* * *} \\
(2.34)\end{array}$ & $\begin{array}{l}.09 * * \\
(2.30)\end{array}$ & $\begin{array}{l}.09 * * \\
(2.19)\end{array}$ & $\begin{array}{l}.09^{* *} \\
(2.14)\end{array}$ \\
\hline Log (roads) & $\ldots$ & $\ldots$ & $\begin{array}{l}.10 \\
(.82)\end{array}$ & $\begin{array}{l}.10 \\
(.78)\end{array}$ & $\begin{array}{l}.08 \\
(.47)\end{array}$ & $\begin{array}{l}.08 \\
(.50)\end{array}$ \\
\hline $\begin{array}{l}\text { HYV share of } \\
\text { rice area } \\
F \text {-statistic: }\end{array}$ & $\ldots$ & $\ldots$ & $\begin{array}{l}.66^{* * *} \\
(2.14)\end{array}$ & $\begin{array}{r}.59 * \\
(1.77)\end{array}$ & $\begin{array}{c}.49 \\
(1.45)\end{array}$ & $\begin{array}{c}.47 \\
(1.34)\end{array}$ \\
\hline $\begin{array}{l}\text { South } \times \text { year } \\
\text { Left Front }\end{array}$ & $\ldots$ & $\ldots$ & $\ldots$ & $\ldots$ & yes & yes \\
\hline $\begin{array}{l}\quad \times \text { year } \\
\text { Sharecropping }\end{array}$ & $\ldots$ & $\ldots$ & $\ldots$ & $\ldots$ & yes & yes \\
\hline $\begin{array}{c}\times \text { year } \\
\text { District fixed }\end{array}$ & $\ldots$ & $\ldots$ & $\ldots$ & $\ldots$ & yes & yes \\
\hline $\begin{array}{c}\text { effects } \\
\text { Year fixed }\end{array}$ & $40.93 * * *$ & $29.34 * * *$ & $6.08 * * *$ & $10.20 * * *$ & $4.51 * *$ & $3.98 * *$ \\
\hline$R^{2} \quad$ effects & $\begin{array}{c}24.39 * * * \\
.89\end{array}$ & $\begin{array}{c}20.20 * * * \\
.89\end{array}$ & $\begin{array}{l}17.71 * * * \\
.90\end{array}$ & $\begin{array}{l}4.36^{* *} \\
.90\end{array}$ & $\begin{array}{l}14.12 * * * \\
.90\end{array}$ & $\begin{array}{c}11.29 * * * \\
.90\end{array}$ \\
\hline
\end{tabular}

NOTE. $-t$-statistics are in parentheses.

* Significant at the 10 percent level.

** Significant at the 5 percent level.

**** Significant at the 1 percent level.

percent during this period, the share of Operation Barga in this improvement was 28 percent.

The impact on sharecropper productivity is obtained by solving the equation for $\gamma$ (from eq. [11]) as follows:

$$
\frac{\lambda_{d} A^{r}+\left(1-\lambda_{d}\right) A^{u}-A^{n}}{A^{o}}=\frac{1-s_{d}}{s_{d}} \gamma \lambda_{d} .
$$

The left-hand side of this expression is the percentage change in the average productivity of sharecroppers offered registration relative to those not offered registration. Multiplying the point estimate of the effect of Operation Barga (0.36) by the take-up rate due to Operation

$0.15)=0.58$. These numbers are obtained by multiplying this number with the point estimate of the coefficient of sharecropper registration. 
Barga (0.58) and the relative importance of sharecropping ([1 $\left.s_{d}\right] / s_{d}=3$ ), we get an estimated effect of 62 percent of Operation Barga on sharecropper yields. This is close to the estimate of 51 percent provided by the difference-in-difference approach using Bangladesh.

\section{Discussion}

Let us compare our estimates of the effect of Operation Barga on sharecropper productivity using various approaches with other studies of the impact of changing incentives on agricultural productivity. The two most closely related studies are Shaban (1987) and Laffont and Matoussi (1995). Shaban analyzed farm-level data from eight Indian villages and estimated that controlling for land quality changing the contractual status of a farm from sharecropper-cultivated to owner-cultivated would increase productivity by 16 percent. ${ }^{48}$ Laffont and Matoussi use farmlevel data from Tunisia to show that a shift from sharecropping to fixedrent tenancy or owner cultivation raised output by 33 percent and moving from a short-term tenancy contract to a longer-term contract increased output by 27.5 percent. ${ }^{49}$ While our estimates are definitely higher, it is worth emphasizing that the 95 percent confidence interval of our estimate goes from 15 percent to 105 percent and therefore includes all the existing estimates. Also, we should probably expect somewhat higher estimates because our measured effect includes the effect of additional investment resulting from the shift in property rights. Shaban's estimate goes up to 32.6 percent when he does not control for land quality. This increase in his estimate should at least partially be interpreted as a measure of the effect of investments in land quality. Finally, as indicated earlier, our estimate is likely to pick up various indirect effects of Operation Barga.

\section{Conclusion}

We concluded from our theoretical analysis that tenancy laws that lead to improved crop shares and higher security of tenure for tenants can have a positive effect on productivity. Evidence based on aggregate district-level data from the Indian state of West Bengal suggests that the

\footnotetext{
${ }^{48}$ See Shaban (1987, table 3). Shaban estimated changes with respect to productivity in owned land (i.e., $\left[A^{o}-A^{n}\right] / A^{o}$ ), and hence these numbers are directly comparable with ours.

${ }^{49}$ Laffont and Matoussi (1995, pp. 391-92) obtain estimates of 50 percent and 38 percent, respectively, but in terms of our notation, what they estimate is $\left(A^{o}-A^{n}\right) / A^{n}$. To make these numbers directly comparable with our estimates or that of Shaban, we compute $\left(A^{o}-A^{n}\right) / A^{o}$ on the basis of their estimates.
} 
tenancy reform program called Operation Barga explains around 28 percent of the subsequent growth of agricultural productivity there. However, given data limitations, we cannot separate the direct and indirect effects of Operation Barga. To get more precise estimates, microlevel data are required, which we leave to future research.

\section{References}

Ackerberg, Daniel A., and Botticini, Maristella "Endogenous Matching and the Empirical Determinants of Contract Form.” J.P.E. 110 (June 2002), in press.

Appu, P. S. "Tenancy Reform in India." Econ. and Polit. Weekly 10 (special issue; August 1975): 1339-75.

Bandiera, Oriana. "On the Structure of Tenancy Contracts: Theory and Evidence from 19th Century Rural Sicily.” Manuscript. London: London School Econ., 1999.

Banerjee, Abhijit V., and Ghatak, Maitreesh. "Empowerment and Efficiency: The Economics of Tenancy Reform.” Manuscript. Cambridge: Massachusetts Inst. Tech. and Harvard Univ., 1996.

Bardhan, Pranab K. "Variations in Extent and Forms of Agricultural Tenancy: Analysis of Indian Data across Regions and over Time." 2 pts. Econ. and Polit. Weekly 11 (September 11, 1976): 1505-12; (September 18, 1976): 1541-46.

Bardhan, Pranab K.; Ghatak, Maitreesh; and Karaivanov, Alexander. "Inequality, Market Imperfections, and the Voluntary Provision of Collective Goods." Manuscript. Berkeley: Univ. California; Chicago: Univ. Chicago, 2002.

Bardhan, Pranab K., and Rudra, Ashok. "Terms and Conditions of Sharecropping Contracts: An Analysis of Village Survey Data in India.” In Land, Labor, and Rural Poverty: Essays in Development Economics, by Pranab K. Bardhan. New York: Columbia Univ. Press, 1984.

Besley, Timothy. "Property Rights and Investment Incentives: Theory and Evidence from Ghana." J.P.E. 103 (October 1995): 903-37.

Bhaumik, Sankar Kumar. Tenancy Relations and Agrarian Development: A Study of West Bengal. New Delhi: Sage Pubs., 1993.

Binswanger, Hans P.; Deininger, K.; and Feder, G. "Power, Distortions, Revolt and Reform in Agricultural Land Relations." In Handbook of Development Economics, vol. 3B, edited by Jere Behrman and T. N. Srinivasan. Amsterdam: North-Holland, 1995.

Boyce, James K. Agrarian Impasse in Bengal: Institutional Constraints to Technological Change. Oxford: Oxford Univ. Press, 1987.

Chadha, G. K., and Bhaumik, S. K. "Changing Tenancy Relations in West Bengal: Popular Notions, Grassroot Realities.” 2 pts. Econ. and Polit. Weekly 27 (May 9, 1992): 1009-17; (May 16, 1992): 1089-98.

Chattopadhyay, B., et al. "Tenancy Reform, the Power Structure and the Role of the Administration: An Evaluation of Operation Barga." Ecoscience CRESSIDA Transactions 3, no. 2 (1984): 1-98.

Das, Prosad K. The Monsoons. 3d ed. New Delhi: Nat. Book Trust, 1995.

Datta, P. K. "Statistics of Bargadars and Extent of Barga Cultivation in West Bengal: An Analytical Study." West Bengal: Government, Directorate Land Records and Survey, 1981.

Dutta, Bhaskar; Ray, Debraj; and Sengupta, Kunal. "Contracts with Eviction in 
Infinitely Repeated Principal-Agent Relationships." In The Economic Theory of Agrarian Institutions, edited by Pranab K. Bardhan. Oxford: Clarendon, 1989.

Eswaran, Mukesh, and Kotwal, Ashok. "A Theory of Contractual Structure in Agriculture.” A.E.R. 75 (June 1985): 352-67.

Fudenberg, Drew, and Tirole, Jean. Game Theory. Cambridge, Mass.: MIT Press, 1991.

Gazdar, Haris, and Sengupta, Sunil. "Agricultural Growth and Recent Trends in Well-Being in Rural West Bengal.” In Sonar Bangla? Agricultural Growth and Agrarian Change in West Bengal and Bangladesh, edited by Ben Rogaly, Barbara Harriss-White, and Sugata Bose. New Delhi: Sage, 1999.

Ghatak, Maitreesh; Morelli, Massimo; and Sjöström, Tomas. "Occupational Choice and Dynamic Incentives.” Rev. Econ. Studies 68 (October 2001): 781-810.

Ghosh, Ratan. "Agrarian Programme of Left Front Government." Econ. and Polit. Weekly: Rev. Agriculture 16 (June 1981): A-49-A-55.

Harriss, John. "What Is Happening in Rural West Bengal? Agrarian Reform, Growth and Distribution." Econ. and Polit. Weekly 28 (June 12, 1993): 1237-47.

Jeon, Yoong-Deok, and Kim, Young-Yong. "Land Reform, Income Redistribution, and Agricultural Production in Korea." Econ. Development and Cultural Change 48 (January 2000): 253-68.

Johnson, D. Gale. "Resource Allocation under Share Contracts." J.P.E. 58 (April 1950): 111-23.

Kohli, Atul. The State and Poverty in India: The Politics of Reform. Cambridge: Cambridge Univ. Press, 1987.

Laffont, Jean-Jacques, and Matoussi, Mohamed Salah. "Moral Hazard, Financial Constraints and Sharecropping in El Oulja." Rev. Econ. Studies 62 (July 1995): 381-99.

Laxminarayan, H., and Tyagi, S. S. "Tenancy: Extent and Inter-state Variations." Econ. and Polit. Weekly 12 (May 28, 1977): 880-83.

"Left Gets It Right.” Economist 328 (July 31, 1993): 33.

Lieten, Georges K. Continuity and Change in Rural West Bengal. New Delhi: Sage, 1992.

Lin, Justin Yifu. "Rural Reforms and Agricultural Growth in China." A.E.R. 82 (March 1992): 34-51.

Mookherjee, Dilip. "Informational Rents and Property Rights in Land." In Property Relations, Incentives, and Welfare, edited by John E. Roemer. London: Macmillan (for Internat. Econ. Assoc.), 1997.

Mookherjee, Dilip, and Ray, Debraj. "Contractual Structure and Wealth Accumulation.” Manuscript. Boston: Boston Univ.; New York: New York Univ., 2000.

Rawal, Vikas. "Agrarian Reform and Land Markets: A Study of Land Transactions in Two Villages of West Bengal, 1977-1995." Econ. Development and Cultural Change 49 (April 2001): 611-29.

Saha, Anamitra, and Swaminathan, Madhura. "Agricultural Growth in West Bengal in the 1980s: A Disaggregation by Districts and Crops." Econ. and Polit. Weekly: Rev. Agriculture 29 (March 26, 1994): A-2-A-11.

Sengupta, Sunil, and Gazdar, Haris. "Agrarian Politics and Rural Development in West Bengal." In Indian Development: Selected Regional Perspectives, edited by Jean Dreze and Amartya Sen. New Delhi: Oxford Univ. Press, 1997.

Shaban, Radwan Ali. "Testing between Competing Models of Sharecropping." J.P.E. 95 (October 1987): 893-920. 
Stiglitz, Joseph E. "Incentives and Risk Sharing in Sharecropping." Rev. Econ. Studies 41 (April 1974): 219-55.

World Bank. The East Asian Miracle: Economic Growth and Public Policy. Policy Research Report. New York: Oxford Univ. Press, 1993. 